\title{
Ferruginous Hawks on the Yakima Training Center
}

R. Mazaika

L. L. Cadwell

July 1994

Prepared for the U.S. Department of the Army under a Related Services Agreement with the U.S. Department of Energy

Contract DE-AC06-76RLO 1830

Pacific Northwest Laboratory

Richland, Washington 99352

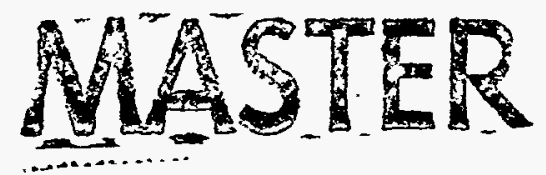




\section{DISCLAIMER}

This report was prepared as an account of work sponsored by an agency of the United States Government. Neither the United States Government nor any agency thereof, nor any of their employees, make any warranty, express or implied, or assumes any legal liability or responsibility for the accuracy, completeness, or usefulness of any information, apparatus, product, or process disclosed, or represents that its use would not infringe privately owned rights. Reference herein to any specific commercial product, process, or service by trade name, trademark, manufacturer, or otherwise does not necessarily constitute or imply its endorsement, recommendation, or favoring by the United States Government or any agency thereof. The views and opinions of authors expressed herein do not necessarily state or reflect those of the United States Government or any agency thereof. 


\section{DISCLAIMER}

Portions of this document may be illegible in electronic image products. Images are produced from the best available original document. 


\section{Summary}

Habitat quality for ferruginous hawks (Buteo regalis) is largely determined by availability of nest sites and adequate prey base. A limitation of one of these will limit the number of hawks in an area. In general, ferruginous hawks are adaptable to various nesting substrates and will nest in proximity to other closely related sympatric species (e.g., red-tailed hawk, Swainson's hawk). This analysis focused on an assessment of prey base availability and habitat disturbance in the vicinity of historic nest sites and small mammal trap sites on the Yakima Training Center (YTC) in Washington State.

The primary ground-disturbing activities on the YTC are associated with military training, fire, and grazing. In addition to the direct effect these activities can have on ferruginous hawks, indirect effects may result from changes in composition, density, and structure of vegetation that subsequently alter faunal population numbers and species diversity.

The primary small mammal species trapped during June through August 1993 were deer mouse (Peromyscus maniculatus), Great Basin pocket mouse (Perognathus parvus), and least chipmunk (Eutamias minimum). Deer mice and Great Basin pocket mice were nocturnally active, with the majority of individuals trapped between approximately 2000 and 0600 hours. Population estimates of small mammal abundance revealed a majority of small-sized, small mammals (e.g., deer mice, Great Basin pocket mice, sagebrush vole) at the trap sites.

Based on enumeration of frequency of disturbance at each of the seven trap sites, the North Bivouac and Hanson Creek sites on YTC were characterized as least disturbed, whereas the Beller site was the most disturbed. The most frequently occurring type of disturbance at the North Bivouac and Hanson Creek sites was cattle grazing, which, it should be noted, has been curtailed at the North Bivouac site since 1991. The most frequently evidenced type of disturbance at the Beller site was use of wheel and track vehicles and disturbed vegetation (e.g., broken sagebrush). Although the use of track vehicles was noted at a similar frequency at another site (the Silica site), examination of training data indicates that use of track vehicles was $50 \%$ more frequent at the Beller site than at the Silica site. This result is of significance when examining the number of small mammals, the diversity of small mammals, and the percent canopy cover of shrubs at these sites. A summary of results for each site is presented in Table S.1.

Examination of ferruginous hawk castings to determine prey selection revealed an increased frequency of occurrence of sagebrush voles (Lagurus curtatus), deer mice, and other Cricetids in the diet of a single nesting pair of ferruginous hawks. Because Leporids were not identifiable to species, diet analysis may not reflect true use of this group of mammals by ferruginous hawks. Comparison . of small mammal, rabbit, bird, and reptile remains indicates a greater frequency of occurrence of small mammals (51\%) and rabbits (31\%) in ferruginous hawk castings. 
Table S.1. Summary of Results of Small Mammal Trapping, Population Estimation, Vegetative Analysis, and Disturbance Rating at Seven Trap Sites, Yakima Training Center, June through August 1993

\begin{tabular}{|c|c|c|c|c|c|c|c|}
\hline . & $\begin{array}{l}\text { North } \\
\text { Bivouac }\end{array}$ & $\begin{array}{c}\text { Training } \\
\text { Area } \\
8 \mathrm{~B} \\
\end{array}$ & $\begin{array}{l}\text { Silica } \\
\text { Site } \\
\end{array}$ & $\begin{array}{c}\text { Range } \\
55\end{array}$ & $\begin{array}{c}\text { Training } \\
\text { Area } \\
9 B \\
\end{array}$ & $\begin{array}{c}\text { Hanson } \\
\text { Creek }\end{array}$ & Beller \\
\hline $\begin{array}{l}\text { Northing/ } \\
\text { easting } \\
\text { coordinates }\end{array}$ & $\begin{array}{l}519189 \\
709586\end{array}$ & $\begin{array}{l}5167337 \\
720249\end{array}$ & $\begin{array}{l}5186358 \\
705532\end{array}$ & $\begin{array}{l}5170437 \\
716406 .\end{array}$ & $\begin{array}{l}5171130 \\
705472\end{array}$ & $\begin{array}{l}5186511 \\
720829\end{array}$ & $\begin{array}{l}5175799 \\
700612\end{array}$ \\
\hline $\begin{array}{l}\text { Species } \\
\text { diversity of } \\
\text { small mammals( }(x)\end{array}$ & High & High & High & High & Low & Low & Low \\
\hline $\begin{array}{l}\text { Number of } \\
\text { small mammals } \\
\text { trapped(b) }\end{array}$ & High & High & Low & Moderate & Low & Low & Low \\
\hline $\begin{array}{l}\text { Population } \\
\text { estimates of } \\
\text { small mammals(c) }\end{array}$ & High & High & Moderate & Moderate & Low & Low & Moderate \\
\hline $\begin{array}{l}\text { Predominant } \\
\text { size of mammals }\end{array}$ & Small-Med & Small-Med & Small & Small & Small-Med & Small & Small-Med \\
\hline $\begin{array}{l}\text { Percent of } \\
\text { bare ground }\end{array}$ & 25.9 & 50.4 & 42.3 & 57.1 & 44.5 & 62.9 & 48.9 \\
\hline $\begin{array}{l}\text { Shrub stem } \\
\text { density(d) }\end{array}$ & High & Low & High & Low & Low & Moderate & High \\
\hline $\begin{array}{l}\text { Species } \\
\text { diversity of } \\
\text { shrubs(e) }\end{array}$ & High & Low & Low & Low & Low & Moderate & Moderate \\
\hline $\begin{array}{l}\text { Percent } \\
\text { canopy of } \\
\text { shrubs(t) }\end{array}$ & High & High & High & Low & Low & High & Moderate \\
\hline $\begin{array}{l}\text { Primary } \\
\text { disturbance }\end{array}$ & Catle & Vehicles & Vehicles & Fire & Fire & Catue & Vehicles \\
\hline Bunchgrasses(g) & Moderate & Low & Low & High & Moderate & Moderate & Moderate \\
\hline Graze units & $\mathrm{E}$ & -. & $\mathrm{E}$ & -- & -- & D & $\mathrm{F}$ \\
\hline $\begin{array}{l}\text { Training areas } \\
\text { pre-Oct } 92\end{array}$ & 3B & $8 \mathrm{~B}$ & $3 \mathrm{~A}$ & $8 \mathrm{~B}$ & $9 B$ & 5 & $1 \mathrm{~A}$ \\
\hline
\end{tabular}

(a) Range in number of species captured $=2$ to 6 (refer to Table 3.6).

(b) Range in number of small mammals trapped $=145$ to 677 (refer to Table 3.5).

(c) Range of total estimated populations $=30.1$ to 141.0 (refer to Table 3.5).

(d) Range of stem densities/ $400 \mathrm{~m}^{2}=3$ to 499 (refer to Table 3.10).

(e) Range in number of species recorded at each trap site $=1$ to 4 (refer to Table 3.9).

(f) Range in percent canopy cover of shrubs $=0.6$ to 22.8 (refer to Table 3.9)

(g) Range in percent canopy cover of bunchgrasses $=19.2$ to 62.1 (refer to Table 3.8). 


\section{Acknowledgments}

This work was funded by the U.S. Department of the Army through a Related Services Agreement with the U.S. Department of Energy under Contract DE-AC06-76RLO 1830. Mr. R. W. Hanna, Chief of the Environmental and Natural Resources Division at Ft. Lewis, was instrumental in obtaining funding for the project.

Several Army and civilian personnel assisted in various aspects of the assessment. The Yakima Training Center (YTC) Range Control officers, Mr. J. H. Hoffman and Mr. J. Reddick, provided logistical support required to work effectively on the YTC. Margaret Taaffe-Pounds, Wildlife Biologist at YTC, contributed to planning and logistical support for this assessment. 


\section{Contents}

Summary $\quad \ldots \ldots \ldots \ldots \ldots \ldots \ldots \ldots \ldots \ldots \ldots \ldots \ldots \ldots \ldots \ldots \ldots \ldots \ldots \ldots \ldots \ldots$

Acknowledgments $\ldots \ldots \ldots \ldots \ldots \ldots \ldots \ldots \ldots \ldots \ldots \ldots \ldots \ldots \ldots \ldots$

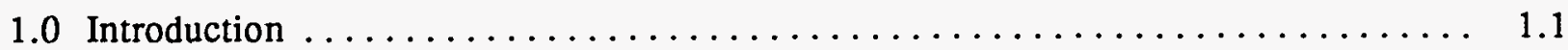

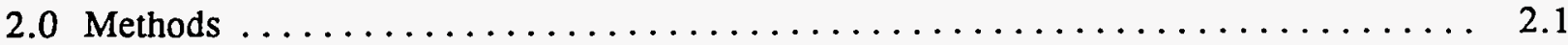

2.1 Area Surrounding Five Historic Ferruginous Hawk Nest Sites $\ldots \ldots \ldots \ldots \ldots$

2.2 Human Disturbance in the Vicinity of Historic Ferruginous Hawk Nest Sites $\ldots \ldots \quad 2.2$

2.3 Index of Abundance of Prey Species and Description of Vegetation and Disturbance Within Small Mammal Trap Sites $\ldots \ldots \ldots \ldots \ldots \ldots \ldots .2$

2.4 Prey Species Selection of a Pair of Nested Ferruginous Hawks . . . . . . . . . . 2.4

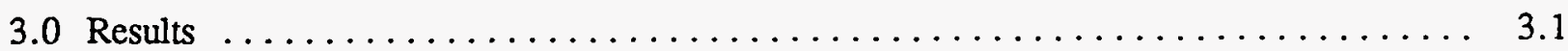

3.1 Nest Sites and Surrounding Areas $\ldots \ldots \ldots \ldots \ldots \ldots \ldots \ldots \ldots \ldots \ldots \ldots \ldots \ldots$

3.2 Human Disturbance Near Nest Sites $\ldots \ldots \ldots \ldots \ldots \ldots \ldots \ldots \ldots \ldots$

3.3 Occurrence and Index to Abundance of Prey Species, Vegetation, and Disturbance Within Small Mammal Trap Sites . . . . . . . . . . . . . 3.25

3.3.1 Prey Species Occurrence $\ldots \ldots \ldots \ldots \ldots \ldots \ldots \ldots \ldots \ldots \ldots \ldots \ldots \ldots \ldots \ldots \ldots \ldots .25$

3.3.2 Index to Abundance of Small Mammals $\ldots \ldots \ldots \ldots \ldots \ldots \ldots \ldots$

3.3.3 Vegetation Distribution $\ldots \ldots \ldots \ldots \ldots \ldots \ldots \ldots \ldots \ldots \ldots \ldots \ldots \ldots \ldots$

3.3 .4 Disturbance $\ldots \ldots \ldots \ldots \ldots \ldots \ldots \ldots \ldots \ldots \ldots \ldots \ldots \ldots \ldots \ldots \ldots$

3.4 Prey Species Selection of a Pair of Nested Ferruginous Hawks . . . . . . . . . 3.35

4.0 Discussion and Conclusions $\ldots \ldots \ldots \ldots \ldots \ldots \ldots \ldots \ldots \ldots \ldots \ldots \ldots \ldots \ldots \ldots \ldots$

4.1 Effects of Grazing on Yakima Training Center $\ldots \ldots \ldots \ldots \ldots \ldots \ldots \ldots .2$

4.2 Human Disturbance on the Yakima Training Center $\ldots \ldots \ldots \ldots \ldots \ldots . \ldots$

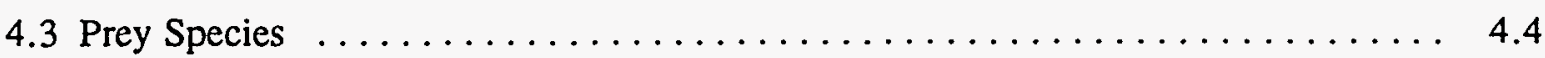

5.0 Management Recommendations $\ldots \ldots \ldots \ldots \ldots \ldots \ldots \ldots \ldots \ldots \ldots \ldots \ldots \ldots$

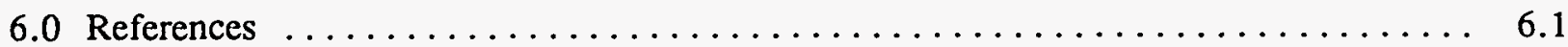




\section{Figures}

3.1 Historic Ferruginous Hawk Nest Sites Surveyed During 1993 on the Yakima

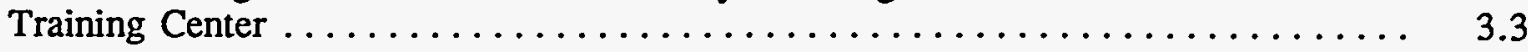

3.21993 Yakima Training Center Grazing Unit Boundaries $\ldots \ldots \ldots \ldots \ldots \ldots \ldots$

3.3 Grazing Unit Activity Yakima Training Center, $1988-1992 \ldots \ldots \ldots \ldots \ldots \ldots$

3.4 Nest Sites and Small Mammal Trap Sites in Relation to Training Areas,

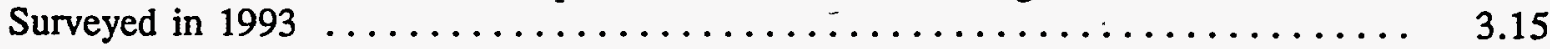

3.5 Training Activity in Training Areas, Yakima Training Center, 1988-1992 _ . . . . 3.17

3.6 Small Mammal Trap Sites in Relation to Grąing Units, Yakima Training Center . . . . 3.27

3.7 Frequency of Occurrence of Small Mammals in Diets of Ferruginous Hawks,

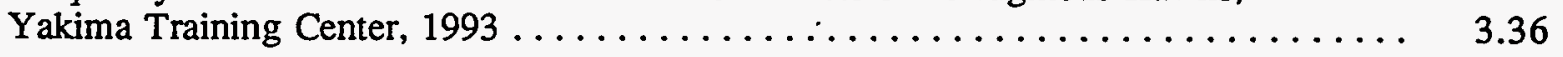

3.8 Frequency of Occurrence of Mammals, Reptiles, and Birds in Diets of Ferruginous Hawks, Yakima Training Center, 1993 


\section{Tables}

S.1 Summary of Results of Small Mammal Trapping, Population Estimation, Vegetative Analysis, and Disturbance Rating at Seven Trap Sites, Yakima Training Center, June through August $1993 \ldots \ldots \ldots \ldots \ldots \ldots \ldots \ldots \ldots \ldots \ldots \ldots \ldots \ldots \ldots$

2.1 Historic Locations of Ferruginous Hawk Nests on the Yakima Training Center $\ldots . .2 .1$

2.2 Coordinates of Trap Sites on Yakima Training Center $\ldots \ldots \ldots \ldots \ldots \ldots \ldots \ldots$

3.1 Percent Canopy Cover of Frequently Occurring Vegetation Species and Bare Ground of the Nest Proper at Historic Ferruginous Hawk Nest Sites on the Yakima Training Center, June through August $1993 \ldots \ldots \ldots \ldots \ldots \ldots \ldots \ldots$

3.2 Mean Diameter and Height of Shrubs Within the Nest Proper at Historic Ferruginous Hawk Nest Sites on the Yakima Training Center, 1993 . . . . . . . . . .

3.3 Grazing Activity on Grazed Units of Yakima Training Center, 1988-1992 . . . . . .

3.4 Training Activities in Training Areas of Yakima Training Center, 1988-1992 . . . .

3.5 Frequency of Occurrence and Estimated Abundance of Small, Medium, and Large Sized Mammal Holes at Seven Trap Sites, Yakima Training Center, 1993 . . . . . . . . .

3.6 Species Diversity of Small Mammals Collected June through August,

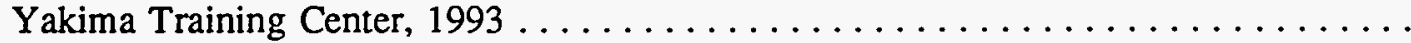

3.7 Occurrence of Small Mammals Captured During Diumal and Nocturnal Trapping Sessions, Yakima Training Center, June through August 1993

3.8 Percent Canopy Cover of Frequently Occurring Vegetation Species and Bare Ground of Small Mammal Trap Sites on the Yakima Training Center, June

3.9 Percent Canopy Cover of Shrub Species at Small Mammal Trap Sites, Yakima

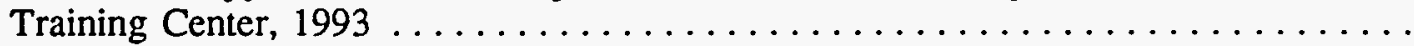

3.10 Number of Stems, Diameter, and Height Recorded at Small Mammal Trap Sites, Yakima Training Center, June through August $1993 \ldots \ldots \ldots \ldots \ldots \ldots \ldots \ldots$

3.11 Type and Frequency of Disturbance at Small Mammal Trap Sites, Yakima Training Center, 1993 


\subsection{Introduction}

Ferruginous hawks (Buteo regalis) are a declining raptor species, and are listed as a "threatened" species in the state of Washington with candidate status for federal listing. Factors which have limited ferruginous hawk population status in the recent past include hawk prey base as a result of habitat degradation from fire, grazing, and cultivation; disturbance associated with human activity; and loss or reduction of nesting habitat. Ferruginous hawks are, generally, intolerant of human activity early in the nesting season (i.e., March-August) and will abandon a nest site or young given a certain level of disturbance.

Egg-laying is initiated between mid-March to mid-April, based on latitudinal location with hatching/rearing in July through August. Ferruginous hawk hatching/rearing success is dependent on abundance and distribution of prey species and ultimately on prey species habitat. Ferruginous hawks are reliant on mammals, primarily on rabbits, jackrabbits, ground squirrels, prairie dogs, and pocket gophers, in varying portions of their range and will switch prey readily based on population densities of prey species. Because of the species' ability to exploit various prey populations, individuals will abandon territories in search of adequate prey base and in response to declines in prey base.

Raptors, as indicators of environmental quality, respond to changes in ecosystem condition by adjusting population distribution or individual productivity. In areas where human disturbance degrades their habitat and reduces their prey population, a species such as the ferruginous hawk may indicate general environmental decline. Howard and Wolfe (1976) concluded that ferruginous hawks consistently fledged more young than other large raptors in favorable areas, but were completely absent from unfavorable habitats. They further speculated that ferruginous hawks dominated their study area because of the presence of highly suitable habitat, which allowed birds to maximize expression of their productivity (Howard and Wolfe 1976).

In an effort to determine the suitability of establishing artificial nest structures for ferruginous hawks on the Yakima Training Center (YTC) in Washington State, researchers from the Pacific Northwest Laboratory, (a) in a project sponsored by the U.S. Department of the Army, assessed the hawks' prey base and characteristics of their prey species habitat (e.g., vegetative composition). Four approaches were used to examine the YTC habitat suitability for ferruginous hawks:

- Five YTC nest sites known to have sustained ferruginous hawks in the past were studied.

- Human disturbance in the vicinity of these nest sites was described.

- An index to abundance of prey species was compiled, vegetation described, and disturbance of prey habitat observed.

- The prey species selected by a pair of nested ferruginous hawks on YTC were determined.

These approaches were drawn from past research that has examined nest distribution (Howard and Wolfe 1976, Gilmer and Stewart 1983, Fitzner and Newell 1989, Schmutz 1987), human disturbance (Sutter and Jones 1981, White and Thurow 1985), food habits and prey species abundance

(a) Pacific Northwest Laboratory is operated for the U.S. Department of Energy by Battelle Memorial Institute under Contract DE AC06-76RLO 1830. 
(Howard and Wolfe 1976, Fitzner et al. 1977, Woffinden and Murphy 1977, Smith and Murphy 1978, Schmutz et al. 1980), and intraspecies interactions (Schmutz et al. 1980, Schmutz 1987, Steenhof et al. 1993).

An additional objective of the study was to provide a literature review of the ferruginous hawk, summarizing existing information on ferruginous hawks applicable to the YTC. Beginning with studies in 1992, this information could provide a basis for the environmental assessment for base realignment activities at Ft. Lewis and the YTC. In addition, the field work was intended to provide basic ecological information on ferruginous hawks on the YTC that can be used to develop management recommendations that minimize the impact of military activities on this species.

Nest distribution of ferruginous hawks may reflect land management activities that have affected habitat suitability. Energy development and other human activities (e.g., agriculture and grazing) have been associated with habitat alteration and disturbance and resultant diminished raptor populations (Sutter and Jones 1981). Clearing or conversion of native vegetation may reduce reproductive success by increasing disturbance, destroying nest sites, and reducing prey populations (Howard and Wolfe 1976). Although reduced prey species abundance is not always an apparent result of human intrusion, prey availability is a primary factor in determining nesting success for all raptors. Raptors may exhibit both numerical or functional responses to reduced prey densities (Phelan and Robertson 1977) by abandoning former nesting habitat or by exhibiting delayed density-dependent responses to reduction in prey base.

Declines in raptor populations have been correlated with declines in prey populations. Woffinden and Murphy (1977) reported a drastic decline in prey population numbers prior to a decline in the raptor population in central Utah. Further, Murphy (1975) observed that the golden eagle population in central Utah exhibited a decline in numbers of nested pairs when populations of its primary prey species (e.g., black-tailed jack rabbits) were reduced. In addition to nest productivity, correlations have been made between changes in prey species abundance and factors such as nest abandonment and mortality, clutch size, and number of nesting attempts (Woffinden and Murphy 1977, Thurow et al. 1980, Smith 1981 et al., Stalmaster 1988). Changes in prey species abundance and diversity, which can be attributed to physical habitat disturbance, should be investigated to establish a baseline with which future monitoring results can be compared.

On the YTC, the primary ground-disturbing activities are associated with military maneuvers, fire, and grazing. Changes in composition, density, and structure of vegetation as a result of these activities can affect changes in faunal populations and, subsequently, in populations of ferruginous hawks. For example, grazing can have a positive effect of opening up habitat to small mammal populations and enhancing raptor foraging opportunities. Alternately, overgrazing can have an effect of reducing plant species that serve as food and cover for small mammals or trampling ground to a point where small mammal nesting is reduced.

Developing a reliable method for assessing prey species habitat or population densities is a necessary prerequisite to raptor population management (Fyfe and Armbruster 1977). Faunal changes associated with varying land uses may be assessed by monthly or annual surveys at active and historic nest sites (Call 1978). This approach has been employed in the Canadian prairie region, where the influence of land-use practices on prey abundance has been used to anticipate effects on raptor density and productivity (Owens and Myers 1973, Hodson 1968). Differences in prey species composition and density contribute to assessment of relative site suitability for ferruginous hawks and other raptor species on the YTC. 
Sections 2.0 and 3.0 are each organized according to the four objectives of the study. Section 2.0 discusses the research methods used; Section 3.0 covers results. A general discussion of findings concludes the report in Section 4.0. 


\subsection{Methods}

In Washington, ferruginous hawks nest in the shrub-steppe region of the lower Columbia Basin (Fitzner et al. 1977). Historically, ferruginous hawks were common in localized areas, but were never abundant due to their limited distribution. Recent increases in nesting pairs of ferruginous hawks on the U.S. Department of Energy's Hanford Site, located approximately $50 \mathrm{~km}$ southeast of the YTC, is likely related to movement of adult birds from offsite areas. Locations of five ferruginous hawk nesting territories have been reported previously for the YTC (Table 2.1). In the recent past, two nest sites have been active: one nest that was occupied and deserted during 1992 and one nest that was occupied and productive during 1993. The nests were located within $0.5 \mathrm{~km}$ of each other and may have been the same pair nesting at the site during 1992 and 1993. The fate of the 1993 nesting attempt was reconstructed from remains of juvenile birds found at the nest proper. There may have been several reasons for failure of the nest, which may have involved abundance and diversity of the prey base on YTC.

The objectives of this analysis were 1) to describe the area surrounding five historic ferruginous hawk nest sites; 2) to describe human disturbance to habitat in the vicinity (i.e., within $1.5 \mathrm{~km}$ ) of five historic ferruginous hawk nest sites; 3 ) to develop an index. of relative abundance of prey species, describe vegetation, and describe disturbance at small mammal trap sites; and 4) to determine prey species selection of a pair of nested ferruginous hawks on the YTC.

Table 2.1. Historic Locations of Ferruginous Hawk Nests on the Yakima Training Center

\begin{tabular}{|c|c|c|c|c|}
\hline \multicolumn{2}{|c|}{ Coordinates } & \multirow[b]{2}{*}{ Location } & \multirow[b]{2}{*}{ Activity } & \multirow[b]{2}{*}{ Source } \\
\hline Northing & Easting & & & \\
\hline 5188931 & 702719 & Squaw Creek & $\begin{array}{l}87 \text { Unoccupied } \\
92 \text { Unoccupied }\end{array}$ & WDFW(a) \\
\hline 5168600 & 727100 & Post 20 & $\begin{array}{l}872 \text { young } \\
88 \text { Occupied } \\
92 \text { Unoccupied }\end{array}$ & WDFW \\
\hline 5174850 & 711700 & Umtanum Ridge & $\begin{array}{l}87 \text { Unoccupied } \\
92 \text { Unoccupied }\end{array}$ & WDFW \\
\hline 5175493 & 698221 & Selah Creek & $\begin{array}{l}88 \text { Unoccupied } \\
92 \text { Unoccupied }\end{array}$ & WDFW \\
\hline 5175264 & 697828 & Selah Creek & $\begin{array}{l}88 \text { Unoccupied } \\
92 \text { Unoccupied }\end{array}$ & WDFW \\
\hline 5166868 & 712896 & Range 11 & 92 Occupied & PNL \\
\hline 5166777 & 713724 & Range 11 & 93 Occupied & PNL \\
\hline
\end{tabular}

(a) Washington Department of Fish and Wildlife (WDFW), Natural Diversity Database, Yakima, Washington. 


\subsection{Area Surrounding Five Historic Ferruginous Hawk Nest Sites}

The locations of historic nest sites presented in Table 2.1 were surveyed to verify nest locations and determine nest activity during 1993. An ambiguity regarding the exact location of the Umtanum Ridge nest site prohibited further analysis at that site. The Selah Creek nest locations were verified and one site was surveyed for our analysis. Two additional nest sites, one identified as active during 1992 and one identified as active during 1993, were surveyed. Drainages within a $1.5-\mathrm{km}$ radius of the five historic nest sites were systematically searched on foot for the presence of ferruginous hawk nests. A 1.5-km buffer was established, based on Stalmaster's (1988) assumption that alternate nests within $1.0 \mathrm{~km}$ of an active nest were in the same territory and that alternate nests outside $1.0 \mathrm{~km}$ represented a separate nesting territory. The $1.5-\mathrm{km}$ buffer was surveyed to determine the presence of additional nests within a "territory" and to identify other nests proximal to the active or historic territory.

The area immediately surrounding the nest site (50-m radius), i.e., the nest proper, was characterized by describing the nest structure, elevation, slope, aspect, distance to valley floor, distance to top of canyon, cliff aspect, distance to water, and distance to disturbance. A 50-m radius was chosen as the nest proper to facilitate comparison of vegetation/disturbance data between nest sites and trap sites. Vegetation near the nest proper was characterized by establishing two $100-\mathrm{m}$ line transects that emanated from the center of the nest site. Vegetation species that occurred along each transect were recorded to develop a relative estimate of percent canopy cover for each species. At 10-m intervals along each transect, percent canopy cover of each species was recorded using a $20-\mathrm{x} 50-\mathrm{cm}$ modified Daubenmire sampling quadrat. Height, diameter, and species were recorded for all shrubs within three 10- $\times 10-\mathrm{m}$ quadrats located at equal intervals along the $100-\mathrm{m}$ transects (total $\mathrm{n}=4$ ). In addition, the total number of shrub species within these quadrats was tallied to determine shrub density. Lastly, a circular area of approximately $200-\mathrm{m}$ diameter was surveyed around the nest proper to compile an overall species list for the site.

\subsection{Human Disturbance in the Vicinity of Historic Ferruginous Hawk Nest Sites}

Occurrence of roads, training areas, ranges, grazing allotments, and burned areas within $1.5-\mathrm{km}$ radius of the nest site were recorded. For purposes of assessing impact to ferruginous hawks during the breeding season, the period of April through August was chosen for review of historic grazing and training data. Training activity data for 1988 to 1992 were examined for each of the training areas that occurred within a $1.5 \mathrm{~km}$ radius of the nest proper. Vehicle type, number of individuals, and number or vehicles were summarized for the historic nest sites included within our analysis. Training activity was summarized for April through August. In addition, grazing intensity was examined for each Grazing Unit for a period between 1988 and 1992.

\subsection{Index of Abundance of Prey Species and Description of Vegetation and Disturbance Within Small Mammal Trap Sites}

Prey species occurrence was determined from seven randomly located trapping grids established across the YTC. Location of trap sites is presented in Table 2.2. Live traps were arranged along a 125- x 25-m grid to determine prey species occurrence. The trapping grid was located at site center and became the point at which vegetation transects, disturbance transects, and prey density 
Table 2.2. Coordinates of Trap Sites on Yakima Training Center

\begin{tabular}{lll}
\cline { 3 - 3 } Trap Site Name & & \multicolumn{2}{c}{ Northing } & Easting \\
\hline Beller Drop Zone & 5175799 & 700612 \\
Silica Site & 5186358 & 705532 \\
Training Area 9-B & 5171130 & 705472 \\
North Bivouac & 5191894 & 709586 \\
Hanson Creek & 5186511 & 720829 \\
Training Area 8-B & 5167337 & 720249 \\
Range 55 & 5170437 & 716406
\end{tabular}

transects emanated. Live traps were baited with rolled oats, peanut butter, and carrots. During June, July, and August of 1993, traps were checked twice daily between 0600 and 0900 and between 1700 and 2000 hours. Live trapping was conducted to determine prey species occurrence.

Burrow holes were counted to provide an index to the population density of various sizes of small mammals. The number and size of holes were recorded along an $800-\mathrm{m}$ transect oriented on the site center. Two observers spaced $10 \mathrm{~m}$ on either side of the transect recorded the number of small, medium, and large mammal holes and the distance from the center line, effectively sampling an 800- x 20-m (1.5-ha) area.

Burrow holes were classified as small $(0-3 \mathrm{~cm})$, medium $(3-6 \mathrm{~cm})$, and large $(>6 \mathrm{~cm})$ for purposes of developing an index of abundance. A census was used because the small mammal trapping was not designed to sample population numbers and in the absence of the animals this physical feature (i.e., holes) was more accessible and easier to count (Davis 1982). From the census of small mammal holes, an index of abundance on a per unit area basis for each trap site was calculated. This index is based on an assumed use of three holes per individual. The assumption that three holes represented an individual animal was used to generate an index to population density so that the number of animals per unit area was not overestimated. The resulting population densities assume that individuals of each size category of mammals excavate an average of three holes. This assumption has not been validated for the YTC and applies to this study only. The index was used to calculate density using Kelker's method (Cox 1969) and assumed that all objects (e.g., holes) were recorded within the strip of $20-\mathrm{m}$ width:

$$
D=\frac{k}{2 L A}
$$

where $\mathrm{D}=$ density of the population per unit area

$A=$ width

$\mathrm{L}=$ length of the transect

$\mathrm{k}=$ total sample size. 
Vegetation was sampled as described in Section 2.1, with two $100-\mathrm{m}$ vegetation transects oriented perpendicular to one another at site center. Disturbance was recorded along the same $100-\mathrm{m}$ vegetation transects within five $10-\times 10$-m quadrats located at equal intervals along each transect $(n=10)$. Disturbance was classified as evidence of track vehicles, wheel vehicles, human debris (e.g., paper, plastic), disturbed vegetation (e.g., broken sagebrush), cheatgrass/knapweed, grazing (e.g., presence of manure), restored vegetation (i.e., colonizing vegetation), fire, and ordnance.

\subsection{Prey Species Selection of a Pair of Nested Ferruginous Hawks}

One active ferruginous hawk nest was identified on the YTC during May 1993. Visits to the site were minimized to avoid disturbance to nested birds. During August 1993, the nest site was visited to gather pellets and prey remains to determine prey species selection of this nested pair. Prey species and their frequency of occurrence were derived from dissecting raptor castings collected at and around the nest site. The nest site was inspected for castings, as were potential perches (e.g., rocks in the outcropping sequence and fence posts) within $1 \mathrm{~km}$ of the test site. A majority of the pellets was collected near the nest site at four perches and at a fence post $210^{\circ}$ southwest of the nest site. The latter location was corroborated by a ferruginous hawk feather collected there. Castings were autoclaved to kill microorganisms and dissected in the laboratory. Skulls, bones, bird feathers, and insect exoskeletons were extracted from the pellets. Small mammals, excluding rabbits, were identified by examining skulls and dentition. Estimates of the number of individual animals were based on the proximity of skull parts to other same-species parts (i.e., an upper whole jaw and a lower whole jaw found in one pellet likely represents an individual, whereas two lower-right jaw bones and a lower-left jaw bone may represent two and possibly three individuals). Because of bone size and fragmentation, it was difficult to isolate intact rabbit skulls in the castings; consequently, a total number of rabbits is not included within results of the dietary analysis. 


\subsection{Results}

Results reported here include the characterization of nest sites and the surrounding areas, human disturbance near nest sites, and the abundance of prey species, vegetation, and disturbance in the areas of trap sites.

\subsection{Nest Sites and Surrounding Areas}

A comprehensive survey of nests was not complete for the entire installation. Nest searches were conducted within a $1.5-\mathrm{km}$ radius of known historic sites during 1993 . Information on historic nest locations including activity was derived from Washington Department of Fish and Wildlife (WDFW) and PNL site records. During 1993, PNL and WDFW staff visited each historic nest site to determine activity. On May 8, 1993, one active nest was located at 713724 E/5166777 N. Subsequent visits to the site were minimized to avoid disturbance to nested ferruginous hawks. Nest searches continued at historic sites (Figure 3.1) between May and August 1993. No additional nests were located.

Elevation at the nest sites ranged between 618 and $945 \mathrm{~m}$. The distance from the nest to the top of the canyon and to the valley floor varied for each site between 2 and $228 \mathrm{~m}$ and 10 and $131 \mathrm{~m}$, respectively. With the exception of the one active ferruginous hawk nest, each historic nest site was oriented on a south- to south-east facing aspect. The one active nest was oriented on a west-facing aspect. Slope varied between $30^{\circ}$ and $75^{\circ}(x=56$ degrees; $n=5)$. In all cases, the nest bowl was constructed on a rock outcrop that was accessible from above. In most instances, perches in the vicinity of the nest site were not observed. This may be attributed to the age of the nests and general state of deterioration of the nest structures. Three of the historic sites were located within 10 to $100 \mathrm{~m}$ of seasonal water (at 10,82 , and $100 \mathrm{~m}$ ).

Land use in the vicinity of the historic sites included grazing and military training activity. Human use of the area was generally light to moderate, with training or use of training facilities constituting the primary disturbance potential. Although all of the sites were located within 0.75 mile of tertiary roads, these roads receive light to moderate use. Larger, more heavily trafficked roads (e.g., I-82) were located between 0.50 and $1.5 \mathrm{~km}$ from the historic nest sites, usually out of the field of view from the site.

Vegetation that occurred consistently within a 200 -m radius of the historic sites included balsamroot (e.g., Balsamorhiza careyana and B. hookeri), tumble mustard (Sisymbrium altissimum), cheatgrass (Bromus tectorum), bluebunch wheatgrass (Agropyron spicatum), Great Basin giant wildrye (Elymus spp.), Sandberg's bluegrass (Poa sandbergii), big sagebrush (Artemisia tridentata), and three-tip sagebrush (A. tripartita).

Percent canopy cover of vegetation within the nest proper was recorded along two $100-\mathrm{m}$ transects and calculated according to Daubenmire (1959). The area within the nest proper was largely unvegetated (Table 3.1). Vegetation that occurred consistently within the nest proper included bluebunch wheatgrass, Sandberg's bluegrass, and cheatgrass although no one species dominated the vegetative component of the sites.

The dominant shrub species occurring within the nest proper was big sagebrush. Total number of shrubs occurring within the nest proper ranged between 0 and 3,050 per ha. Shrub diameter 



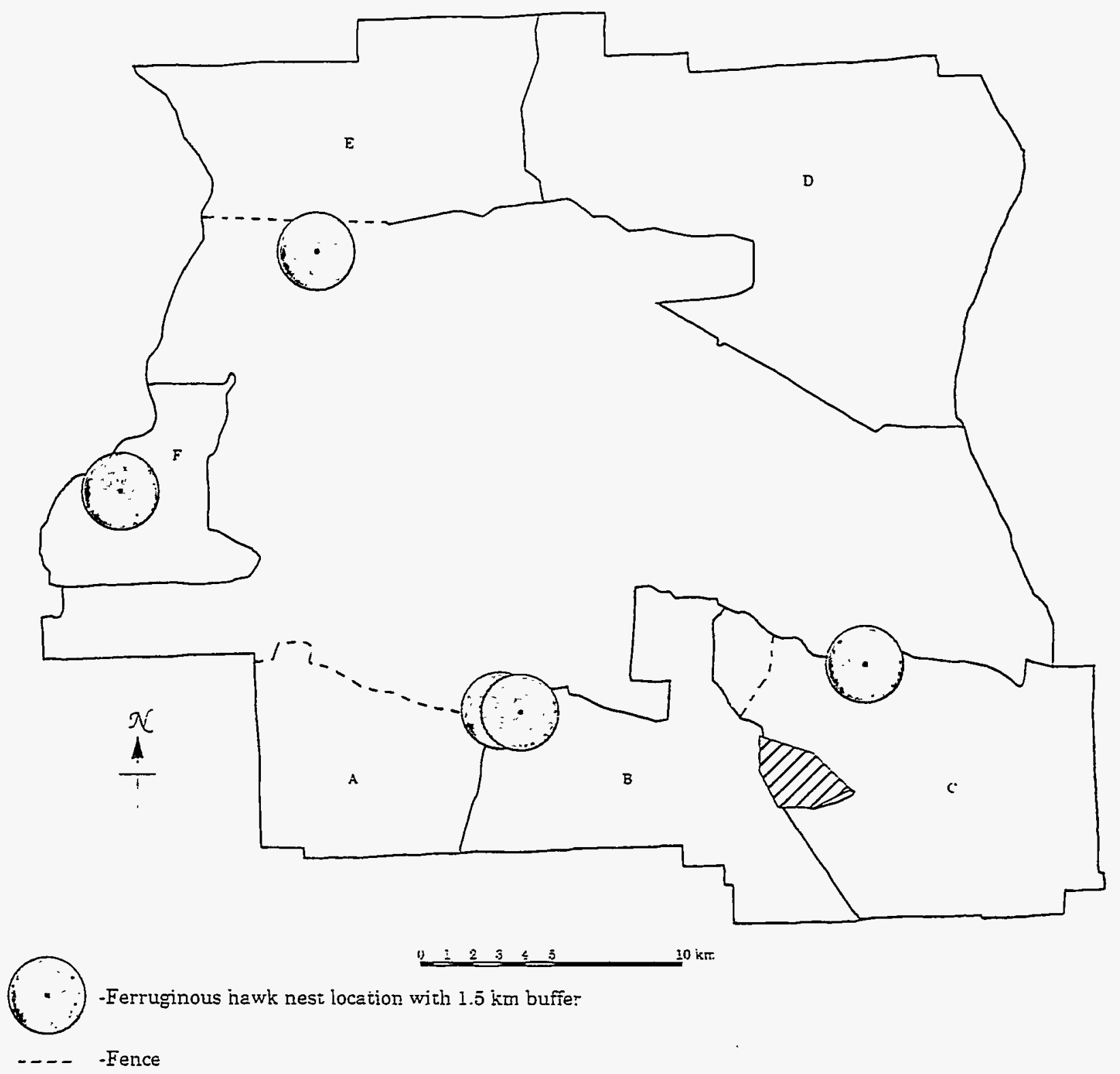

Figure 3.1. Historic Ferruginous Hawk Nest Sites Surveyed During 1993 on the Yakima Training Center

ranged between 34 and $180 \mathrm{~cm}$ (Table 3.2). The majority (97\%) of shrubs ( $\mathrm{n}=215$ ) in the 0.2 -ha sample area ranged between 34 and $62 \mathrm{~cm}$ in diameter. Shrub height ranged between 24 and $98 \mathrm{~cm}$ (Table 3.2), with the majority (90\%) ranging between 24 and $40 \mathrm{~cm}(\mathrm{n}=199)$.

\subsection{Human Disturbance Near Nest Sites}

Severity of disturbance to ferruginous hawks varies relative to the line of sight of the activity to the birds, security of the nest site, and amount of past disturbance (Snow 1974, Stalmaster 1985). 

Table 3.1. Percent Canopy Cover of Frequently Occurring Vegetation Species and Bare Ground of the Nest Proper at Historic Ferruginous Hawk Nest Sites on the Yakima Training Center, June through August 1993

\begin{tabular}{|c|c|c|c|c|c|}
\hline \multirow{2}{*}{ Species } & & & & & \\
\hline & 1 & 2 & 3 & 4 & 5 \\
\hline Agropyron spicatum & 20.9 & 2.6 & 6.9 & 19.1 & 19.4 \\
\hline Poa sandbergii & 10.5 & 3.5 & 4.9 & 4.9 & 11.4 \\
\hline Bromus tectorum & 6.6 & 11.6 & 5.5 & 23.6 & 0.9 \\
\hline Achillea millefolium & 0.1 & 0.9 & 0.1 & 0.9 & 0.3 \\
\hline Descurainia sophia & 0.5 & 1.9 & 0.3 & 1.0 & -- \\
\hline Epilobium spp. & 0.5 & 1.1 & -- & 3.8 & 1.1 \\
\hline Lomatium spp. & 8.0 & - & 2.0 & - & 1.5 \\
\hline Balsamorhiza careyana & 1.5 & -- & 0.8 & -- & 0.1 \\
\hline Sisymbrium altissimum & 0.3 & 1.8 & 6.1 & -- & -- \\
\hline Bare ground & 43.6 & 58.6 & 26.3 & 46.8 & 29.4 \\
\hline
\end{tabular}

Table 3.2. Mean Diameter and Height of Shrubs Within the Nest Proper (50-m Radius) at Historic Ferruginous Hawk Nest Sites on the Yakima Training Center, 1993

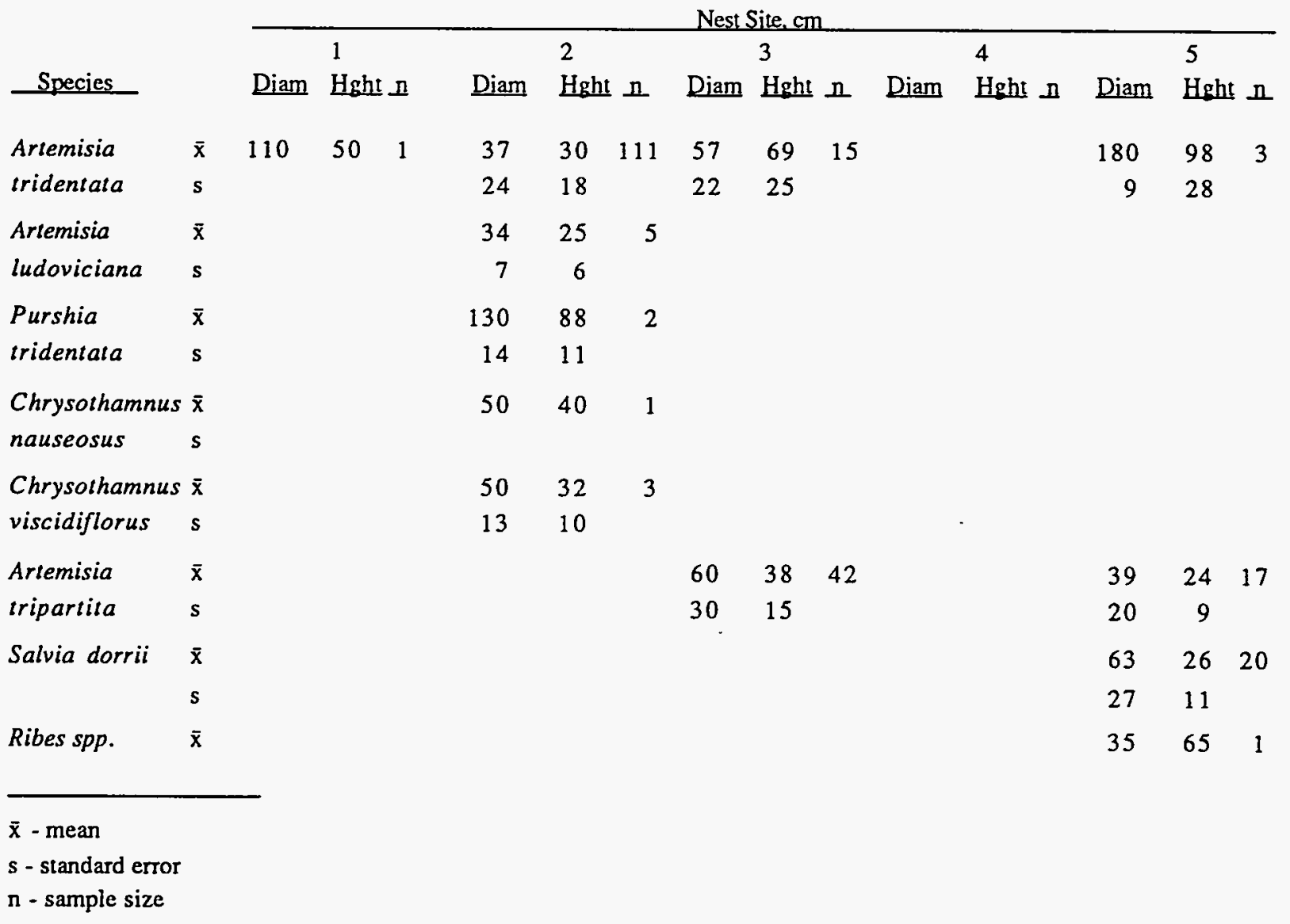


Disturbance in the vicinity of historic nest sites was described with reference to land use, human use, and roads. The predominant land use and associated disturbance in the vicinity of historic nest sites can be attributed to grazing and military training activities. Because disturbance can be recorded and past disturbance can be corroborated from site conditions (i.e., tire tracks, knapweed, broken plants) or from site records (i.e., training data), we chose to examine disturbance in the vicinity of historic nest sites over the previous 5 years (e.g., 1988-1992). During 1993, human use of these sites was generally light to moderate (ranging from 1 to 3 based on Stalmaster's [1985] criteria for rating human activity), with training or use of training facilities constituting the primary disturbance potential. Stalmaster's (1985) ranking designates human activity intensity scores of 1 for jeep trails, incidental activities, pipelines, and unoccupied buildings; 2 for unimproved roads, powerlines, airstrips; and 3 for light-duty roads, drillholes, oil and gas wells, railroads, and sheep camps. The sites were located within 0.75 miles of tertiary roads; larger, more heavily trafficked roads (e.g., I-82) were located between 0.50 and $1.5 \mathrm{~km}$ from several nest sites, usually out of the field of view from the site.

Each of the five historic nest sites occurs within one of six grazing units on the YTC (Figure 3.2). Sites 1 and 5 are located within Grazing Unit B. In 1990, grazing activity within this unit was eliminated, and since then the unit has not been grazed (Figure 3.3). It should be noted that Site 5 was the location of the active ferruginous hawk nest during 1993. Site 2 is located near Grazing Unit E. Grazing activity in this unit has decreased steadily since 1990. During 1992, grazing intensity was greatest during May, accommodating 125 animal units months (AUMs) (see Table 3.3). Site 3 is located within Grazing Unit F. As in units A, C, and E, grazing intensity has decreased steadily since 1990 (see Figure 3.3). During 1992, no grazing activity was reported for Unit $F$ during the period of ferruginous hawk nesting. Site 4 is located within Grazing Unit $C$, where grazing intensity decreased markedly between 1990 and 1991 and continued to decrease through 1992 (see Figure 3.3).

Each of the historic nest sites occurs in the vicinity of one or several training areas (Figure 3.4). Activity within these areas was summarized for the period of ferruginous hawk activity (e.g., AprilAugust) between 1988 and 1992. Dispatch of military personnel and vehicles in these areas is reported as user days per month. Gaps in 1992 data may suggest lack of a complete data set for that year. Overall training activity has decreased across all training areas on the YTC with periods of peak use generally reported for June.

- Sites 1 and 5 are proximal to Training Areas 10B, 10C, 11A, and 11C. Training activity (e.g., use of wheel/track vehicles and personnel) in these areas has decreased since 1990 (Figure 3.5). Maximum numbers of track and wheel vehicles dispatched in these areas $(2,104)$ was reported for June 1989 and maximum number of user days in these areas was reported for June 1990 $(20,292)$ (see Table 3.4).

- Site 2 is proximal to Training Areas 2A, 3A, 2B, and 3B. Use of track and wheel vehicles generally decreased in this area after 1990, with the period of maximum use reported for June 1989, when 2,759 wheel and 1,228 track vehicle user days were reported for this area. The number of user days has also decreased since 1990 , with a maximum number $(28,663$ user days) reported for June 1990 (see Table 3.4). Training Areas 2A, 2B, 3A, and 3B are more heavily trafficked by vehicles than are the other training areas. Similarly, these training areas report a greater number of user days compared to other training areas. Training Areas 10B, $10 \mathrm{C}, 11 \mathrm{~A}$, and $11 \mathrm{C}$ have also received heavy training activity although it appears from the record that the number of vehicles dispatched to these areas has generally been fewer than to Training Areas 2A, 2B, 3A, and 3B. 


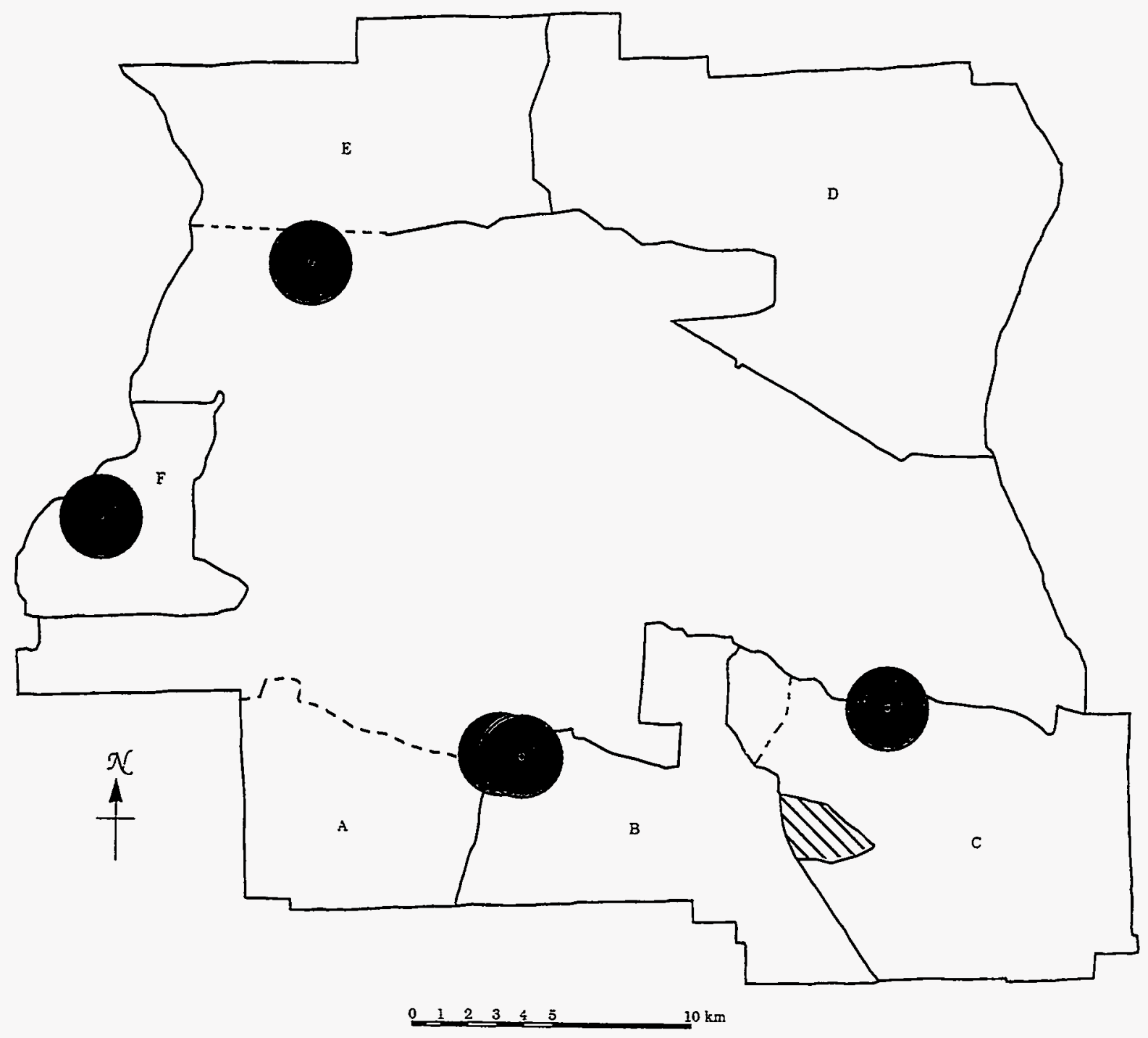

-Ferruginous hawk nest location with $1.5-\mathrm{km}$ buffer

$-\ldots-$-Fence

-Grazing unit boundary

Figure 3.2. 1993 Yakima Training Center Grazing Unit Boundaries (Blank area in interior is not grazed.) 
Unit A 1988-1992

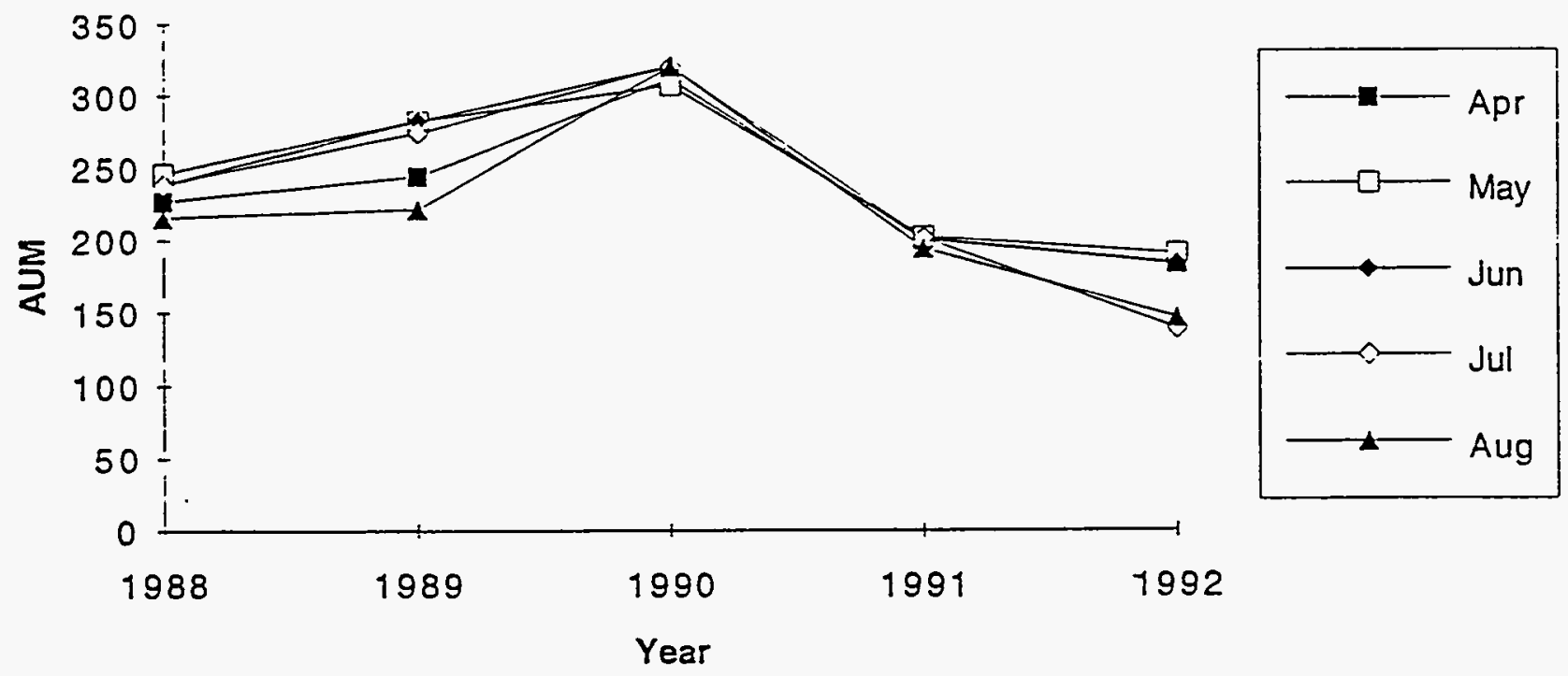

\section{Unit B 1988-1992}

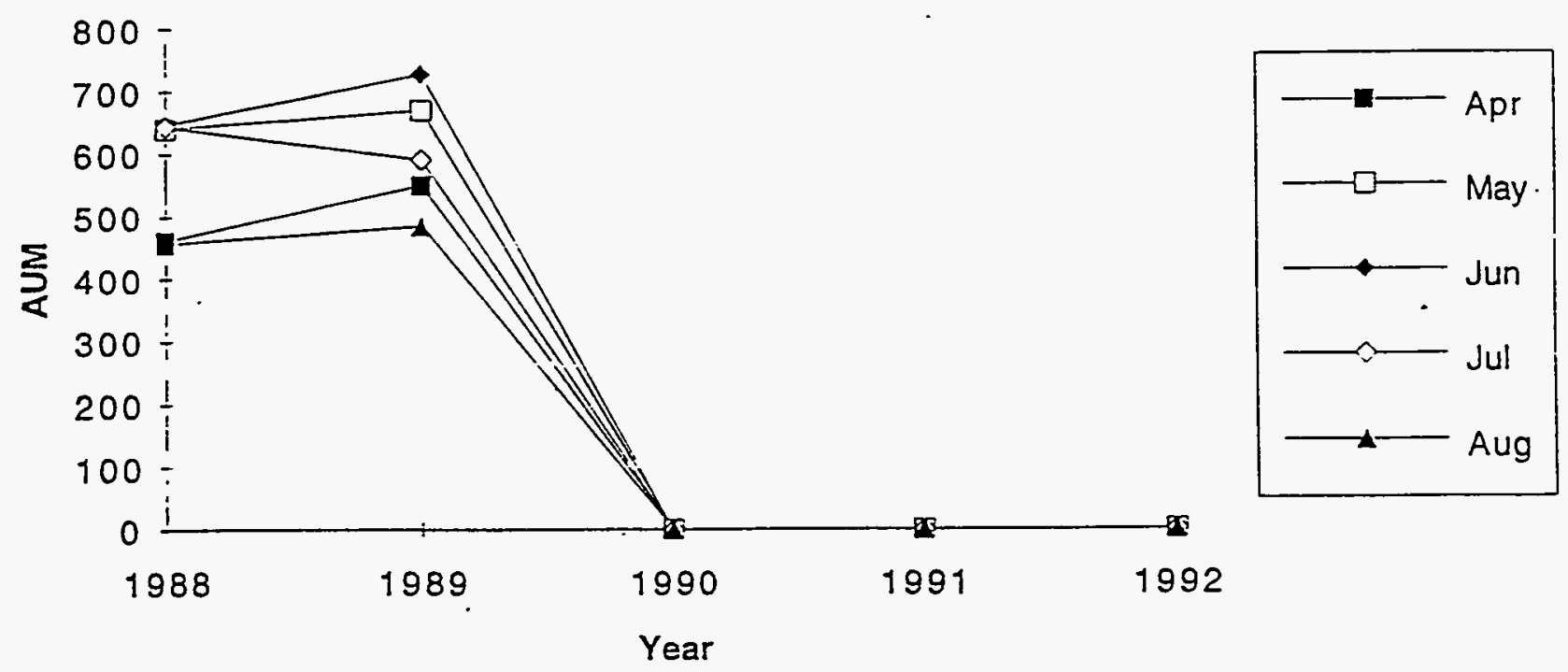

Figure 3.3. Grazing Unit Activity, Yakima Training Center, 1988-1992 


\section{Unit C 1988-1992}

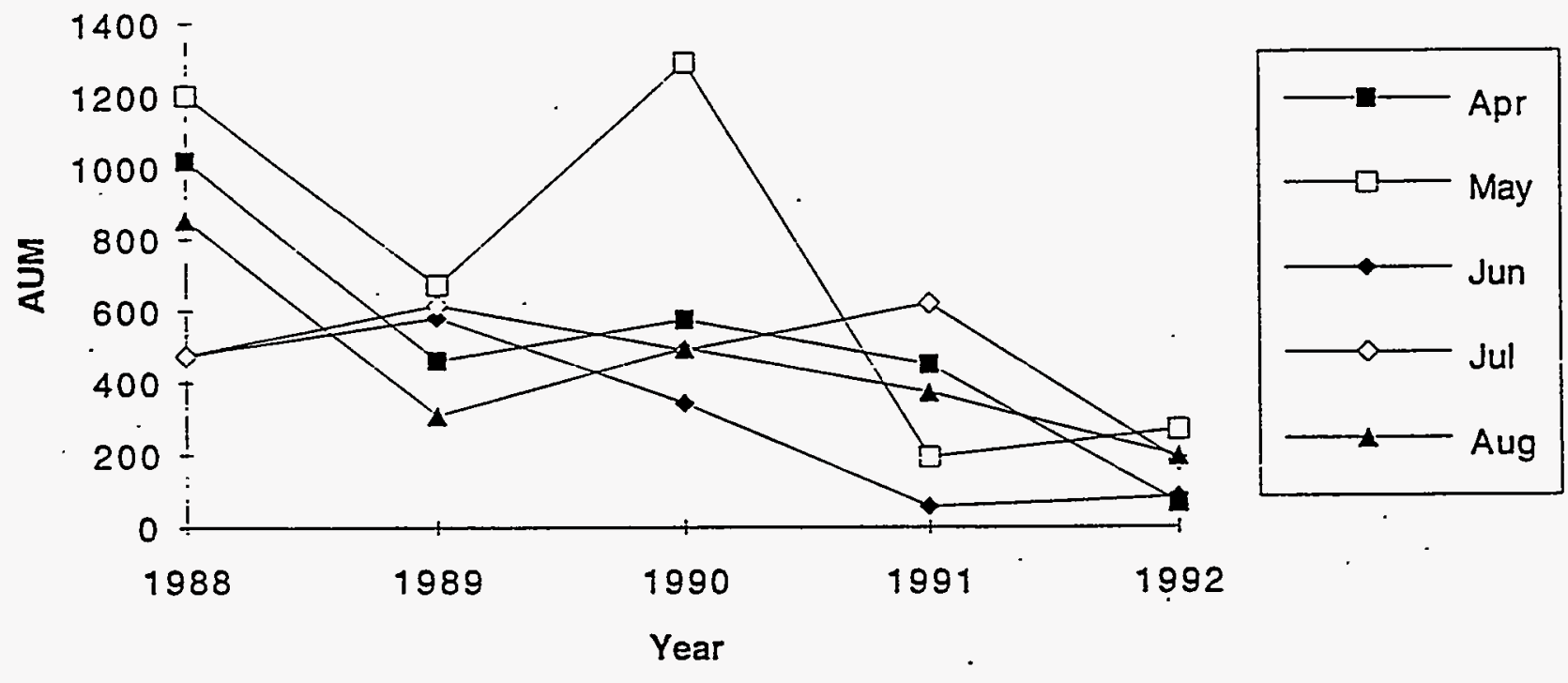

Unit D 1988-1992

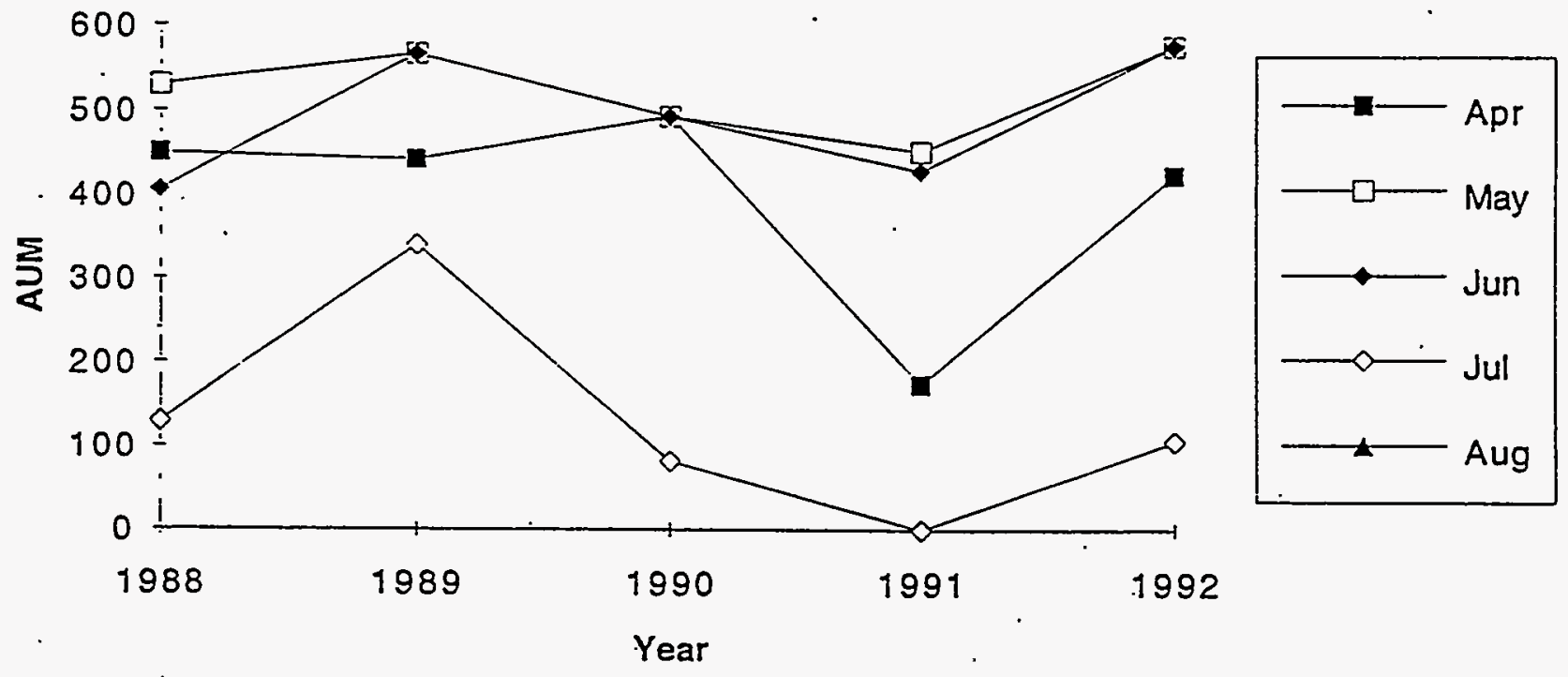

Figure 3.3. (contd) 


\section{Unit E 1988-1992}

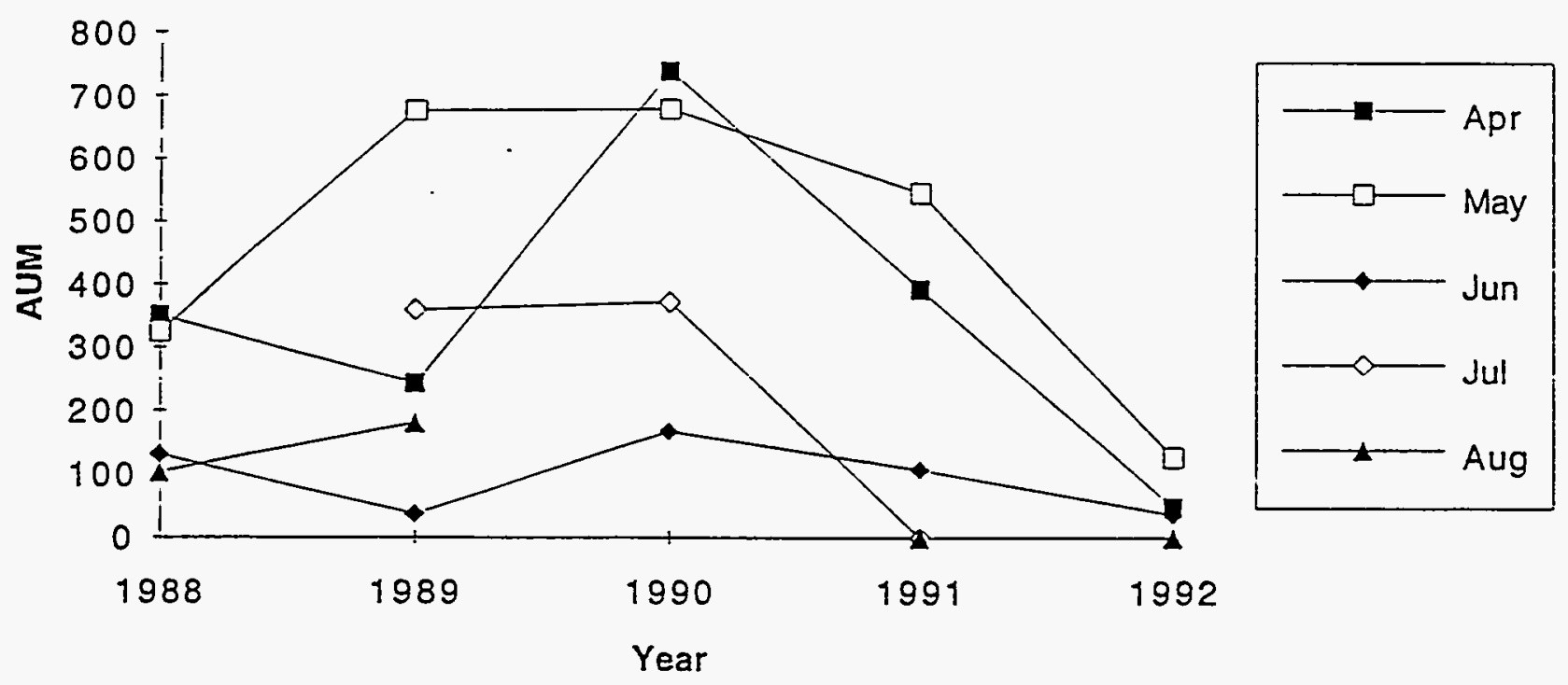

Unit F 1988-1992

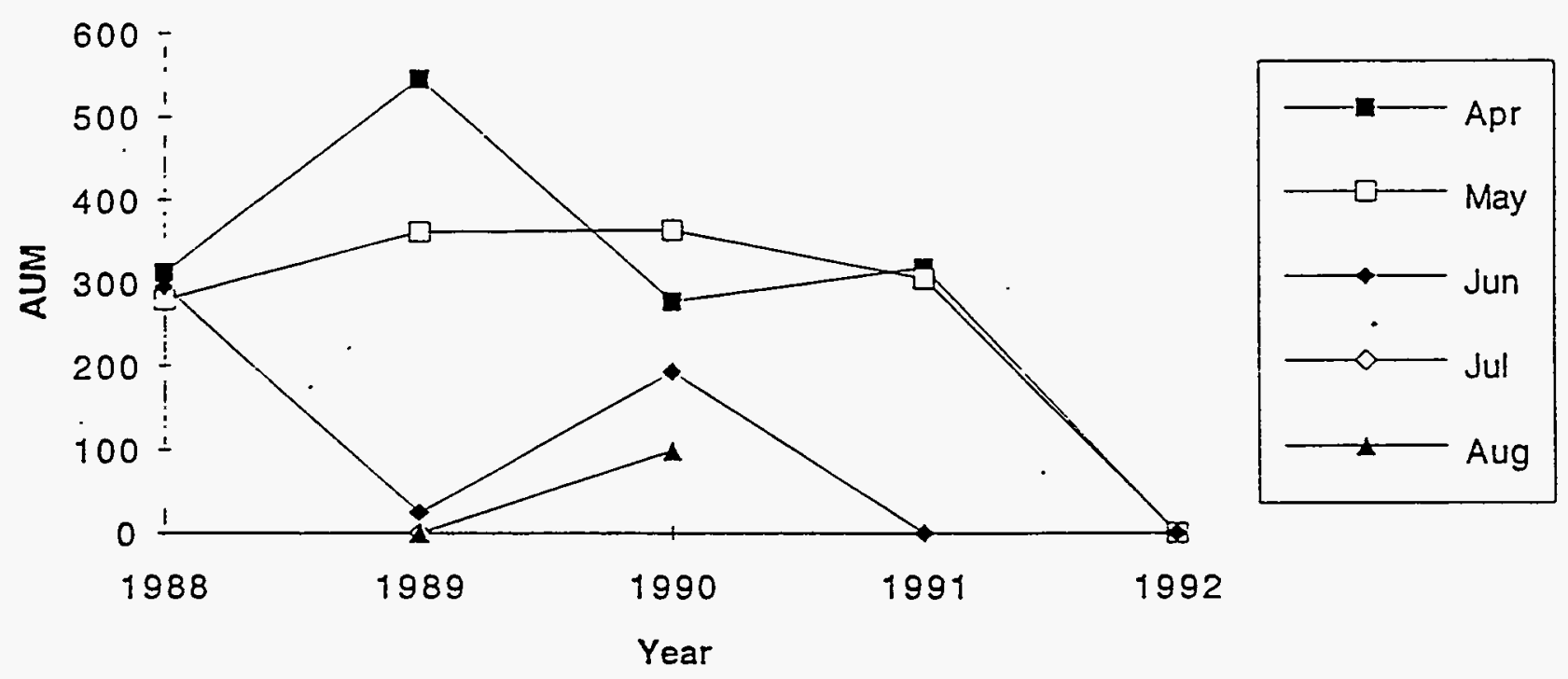

Figure 3.3. (contd) 
Table 3.3. Grazing Activity on Grazed Units of Yakima Training Center, 1988-1992

Units and

Months

Unit A

Mar
Apr
May
Jun
Jul
Aug
Sep
Oct
Nov
Dec

Unit F

Mar
Apr
May
Jun

Jul

Aug

Sep

Oct

Nov

Dec

Jan

Feb

Unit B

Mar

Apr

May

Jun

Jul

Aug

Sep

Oct

Nov

Dec
Animal Units

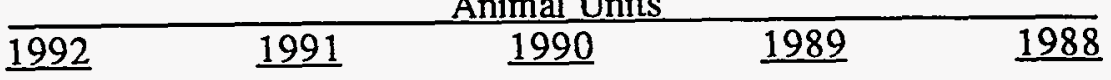

200

202

201

201

194

174

161

171

182

43

43

56
37

227

246

238

238

216

193

193

160

$\begin{array}{ll}187 & 160 \\ 175 & 131\end{array}$
317

304

362

193

99

379

204

204

278

28

$\begin{array}{ll}545 & 312 \\ 360 & 279\end{array}$

$24 \quad 295$

204

610
617

730

$\begin{array}{rr}74 & \\ 430 & \\ 375 & 617 \\ 746 & 730\end{array}$

548

669

726

590

483

483
57

461

640

646

644

456 
Table 3.3. (contd)

Units and

Months

Unit C

$\begin{array}{lr}\text { Mar } & \\ \text { Apr } & 66 \\ \text { May } & 268 \\ \text { Jun } & 83 \\ \text { Jul } & 181 \\ \text { Aug } & 196 \\ \text { Sep } & 154 \\ \text { Oct } & 165 \\ \text { Nov } & 296 \\ \text { Dec } & 304\end{array}$

Unit D

$\begin{array}{ll}\text { Mar } & \\ \text { Apr } & 423 \\ \text { May } & 575 \\ \text { Jun } & 575 \\ \text { Jul } & 105 \\ \text { Aug } & \\ \text { Sep } & \\ \text { Oct } & \\ \text { Nov } & \\ \text { Dec } & \\ \text { Jan } & \\ \text { Feb } & \end{array}$

Unit E

Mar
Apr
May
Jun
Jul
Aug
Sep
Oct
Nov
Dec
Jan
Feb

Total

$\underline{1992}$

Animal Units 1990

1989

1988

155

394

176

364

738

406
462

671

579

615

309

289

289

57

450

530

406

129

340

538

1018

1201

474

474

854

474

474

399

442

567

567

129

467
47

125

36

393

545

106

739

679

167

372

177

198

326

327

756

8306

5858

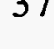

229

914

453

14949
23

351

325

131

360

180

102

412

394

382

363

298

48 


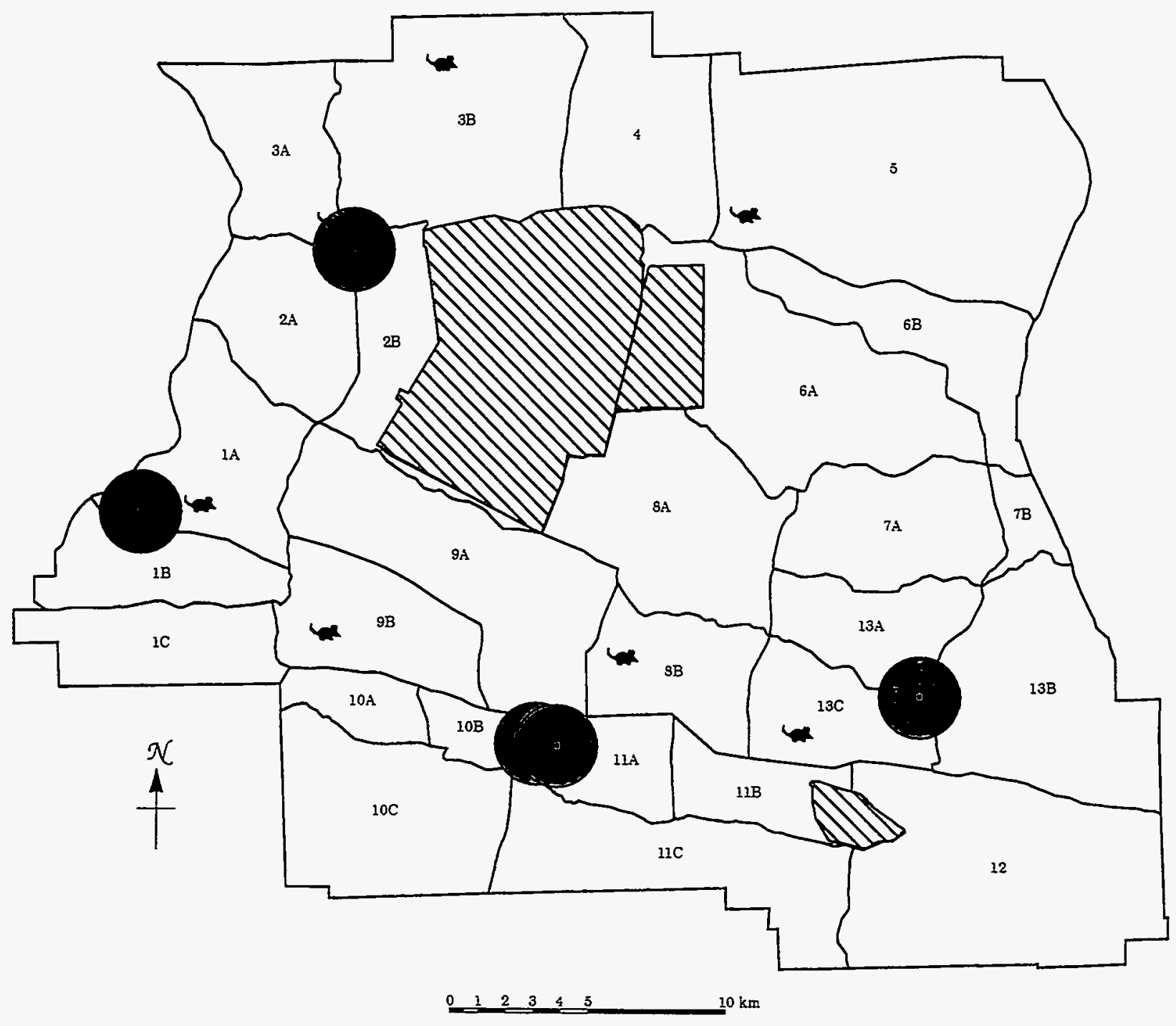

-Ferruginous hawk nest location with $1.5-\mathrm{km}$ buffer

-Trap site

-Areas include Impact Area. Multi-Purpose Range Maneuver Area, and Dud Area

Figure 3.4. Nest Sites and Small Mammal Trap Sites in Relation to Training Areas, Surveyed in 1993 

TA 1A/TA 11B

\section{Wheel Vehicle}

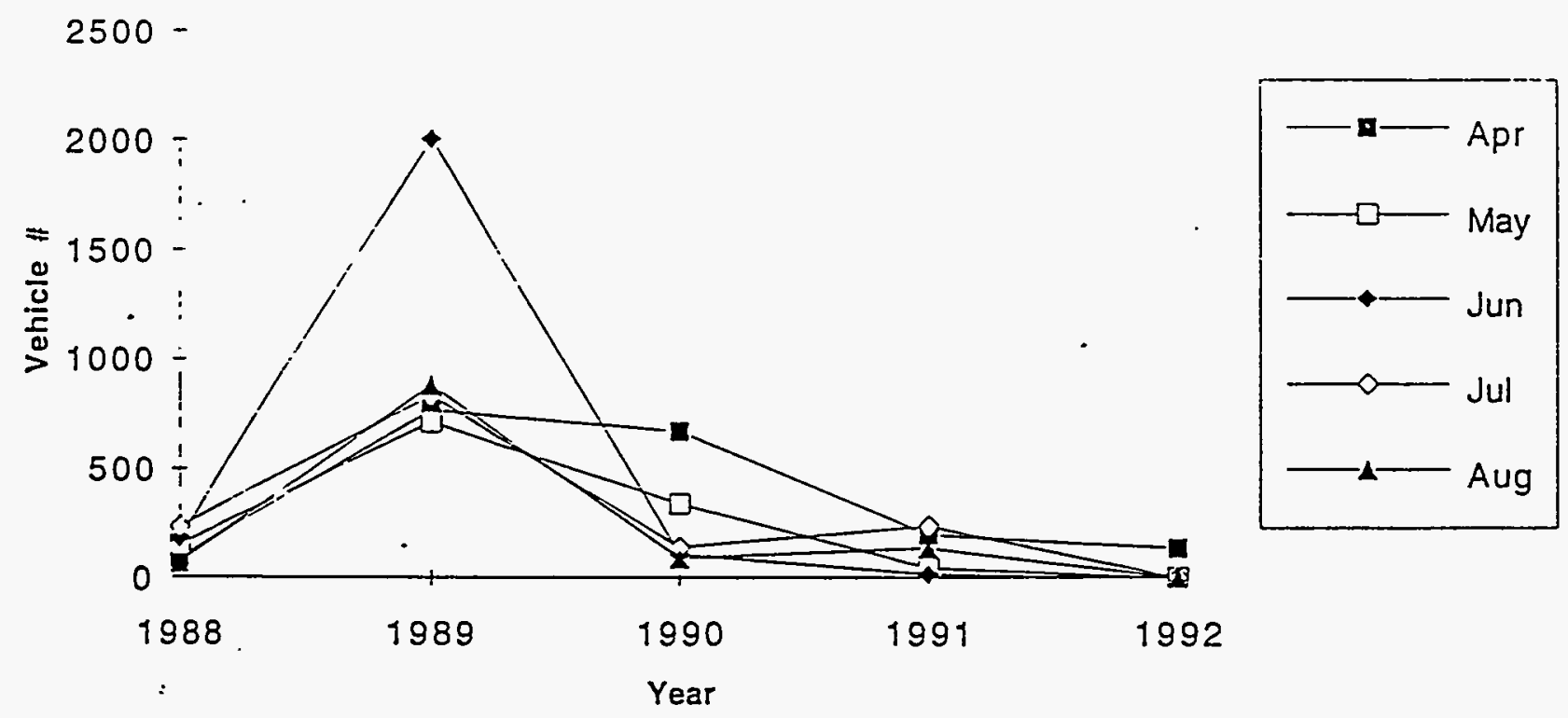

TA 1A/TA 11B

Track Vehicle

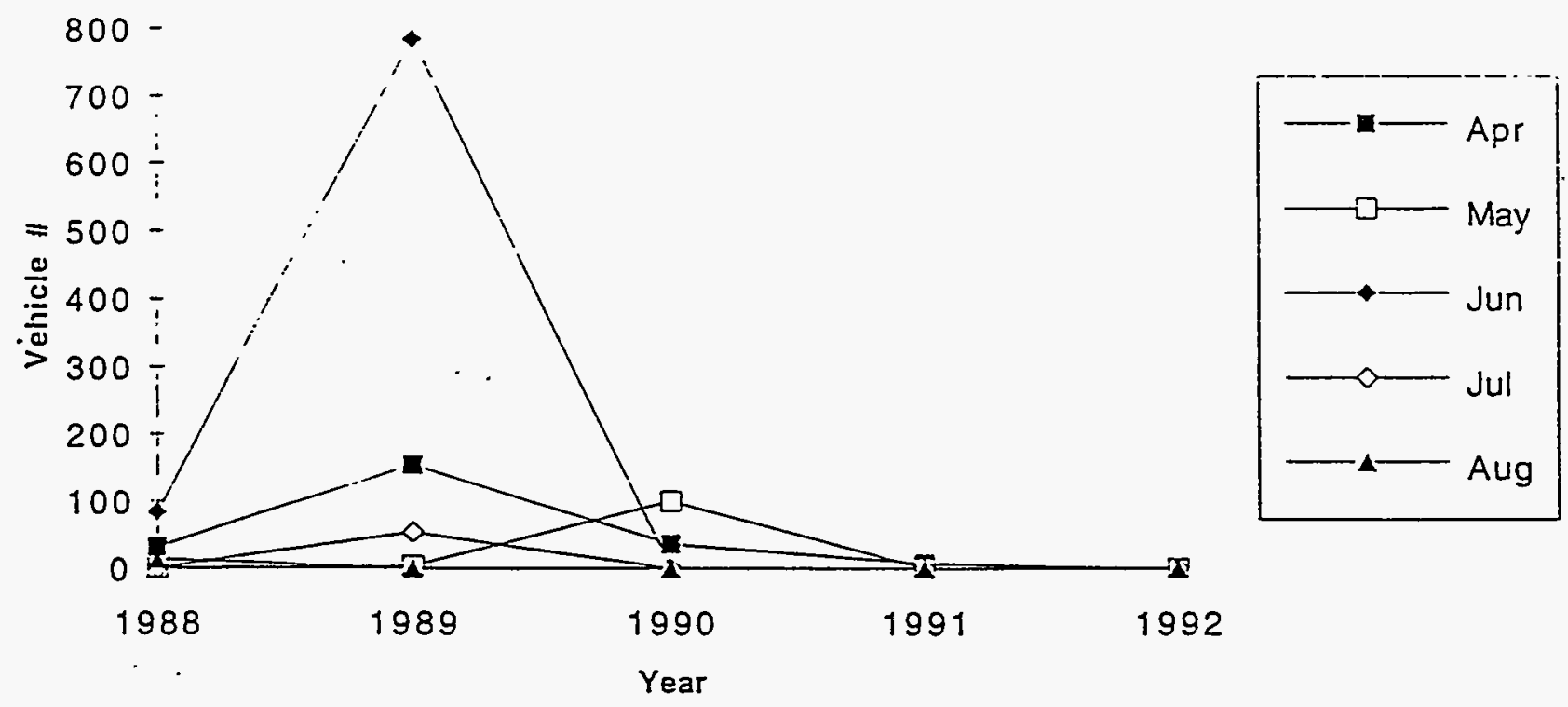

Figure 3.5. Training Activity in Training Areas, Yakima Training Center, 1988-1992 
TA 1A/TA 11B

Personnel Dispatch

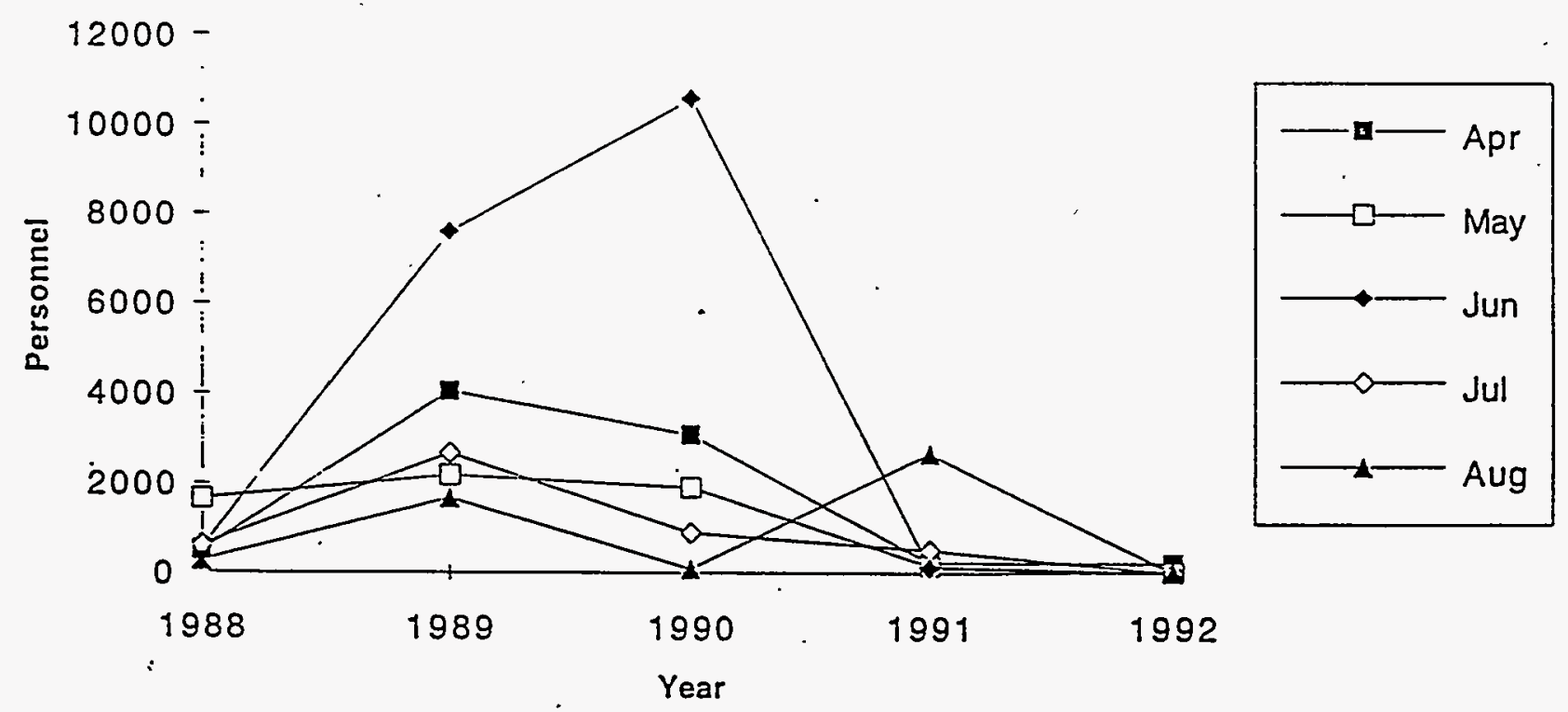

TA 2A/ TA 2B/ TA 3A/ TA 3B

Wheel Vehicle

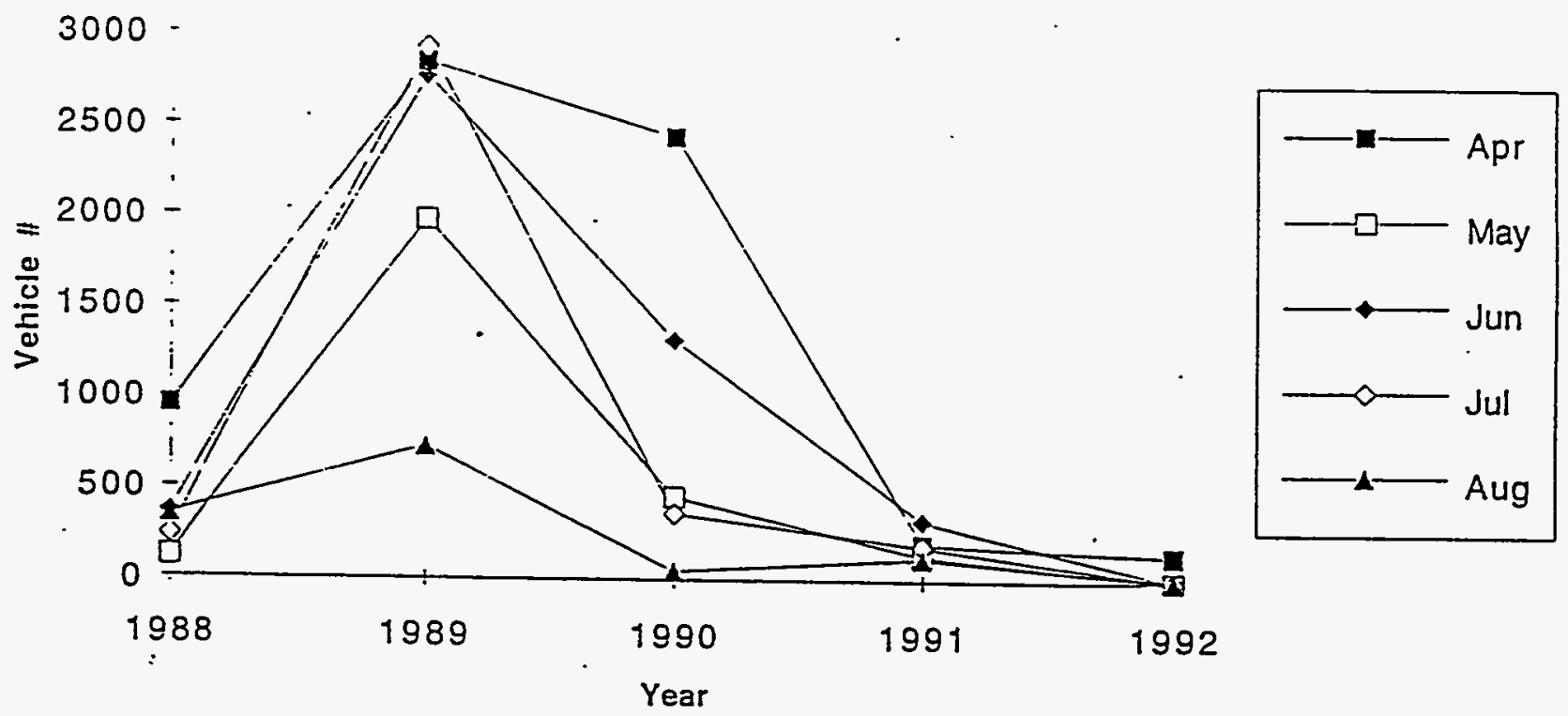

Figure 3.5. (contd) 
TA 2A/ TA 2B/ TA 3A/ TA 3B

\section{Track Vehicle}

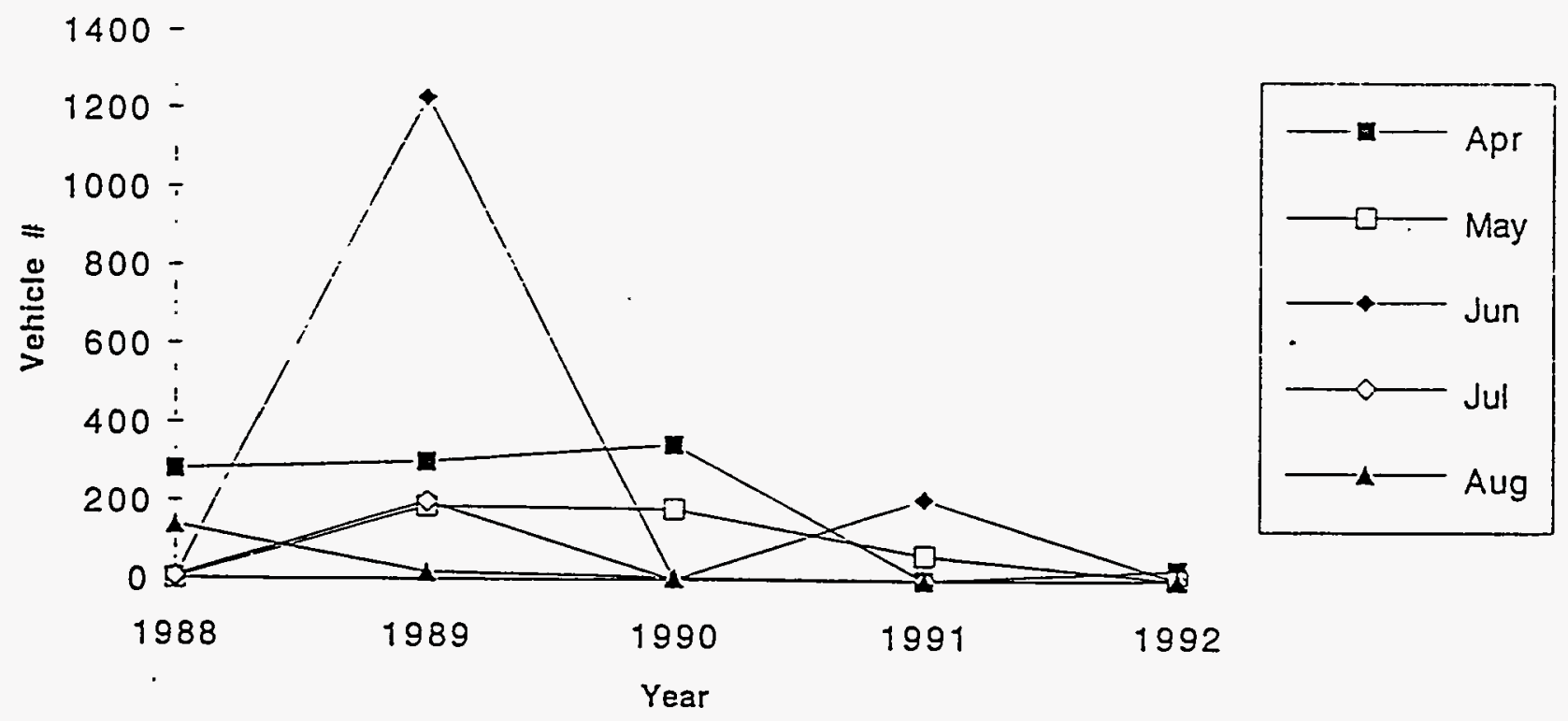

TA 2A/ TA 2B/ TA 3A/ TA 3B

\section{Personnel Dispatch}

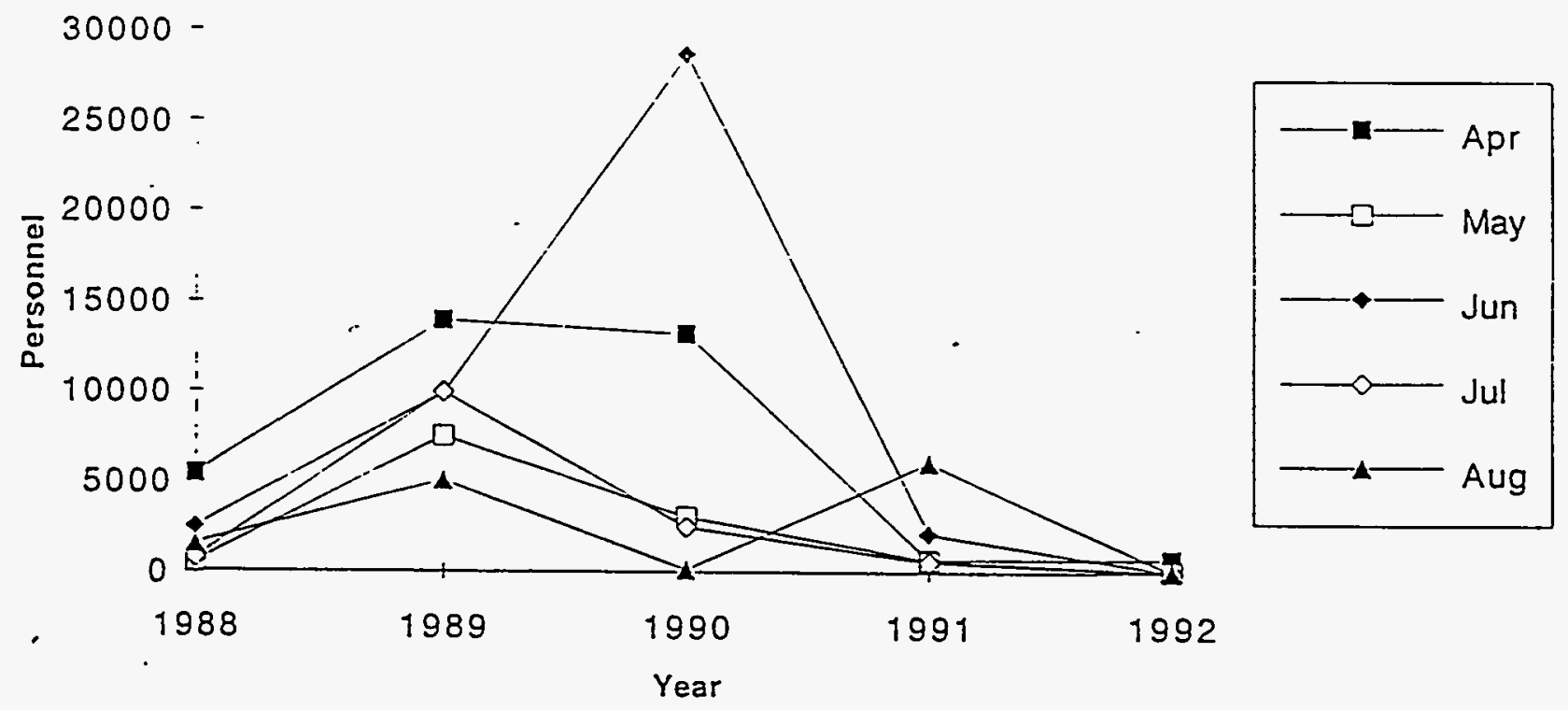

Figure 3.5. (contd) 
TA 10B/ TA 10C/ TA 11A/ TA 11C

Wheel Vehicle

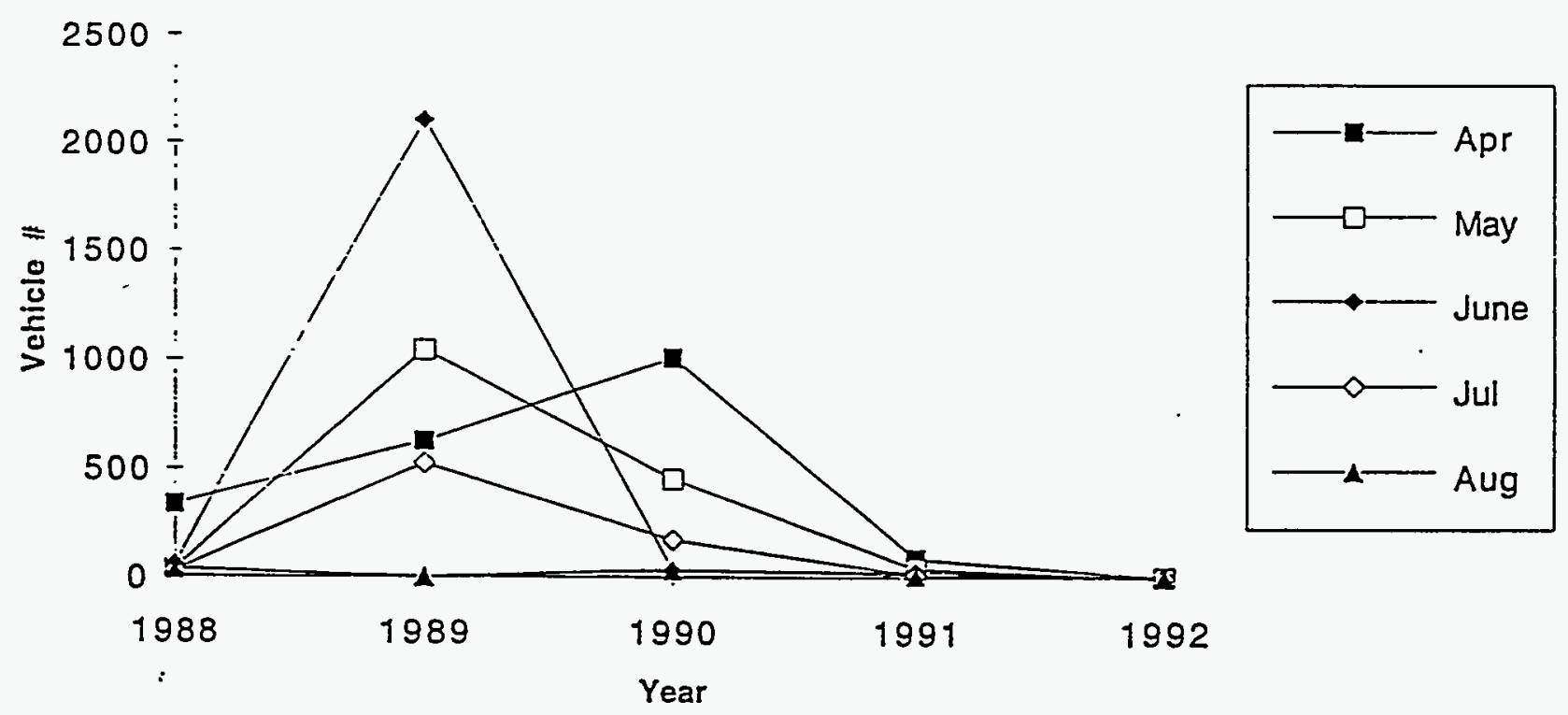

TA 10B/TA 10C/ TA 11A/ TA 11C

Track Vehicle

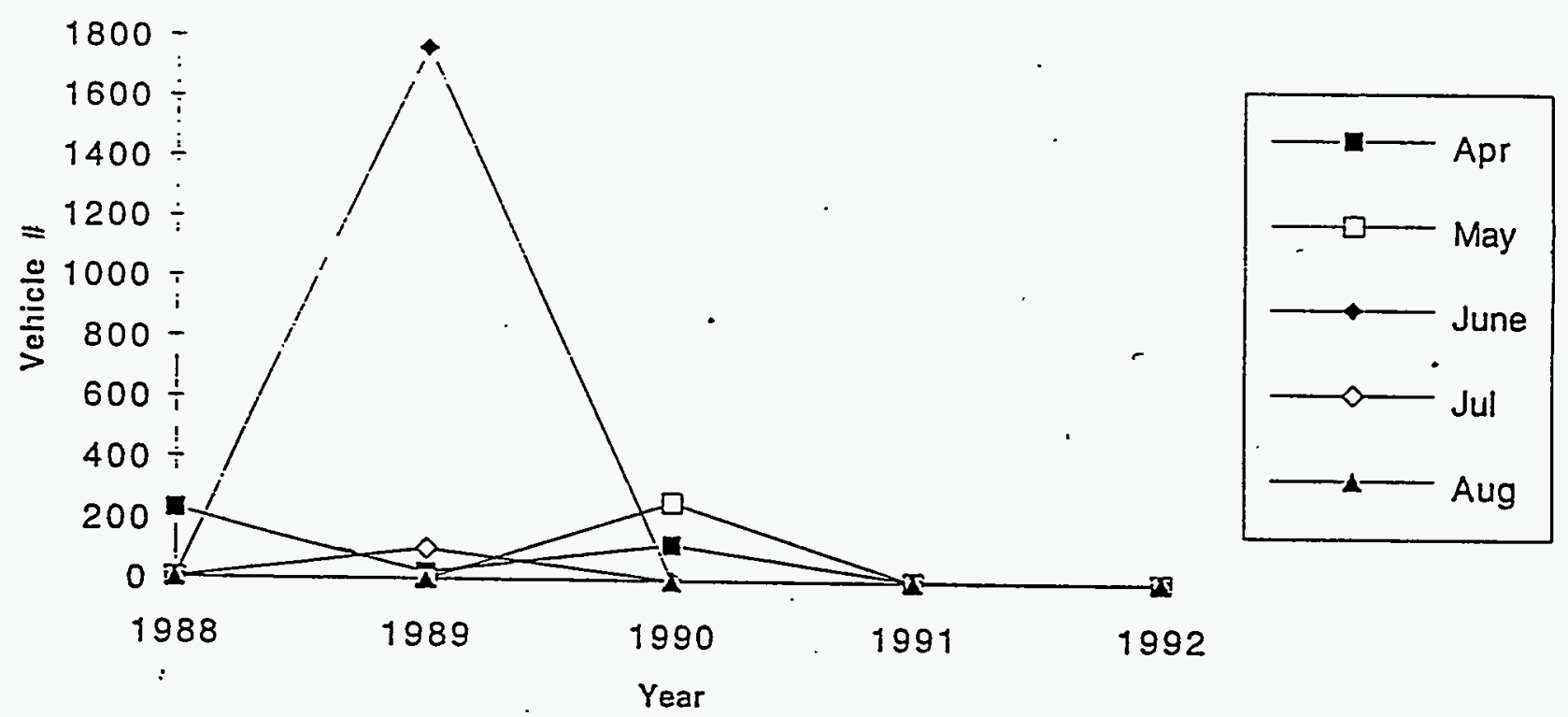

Figure 3.5. (contd) 
TA 10B/TA 10C/ TA 11A/ TA 11C

Personnel Dispatch

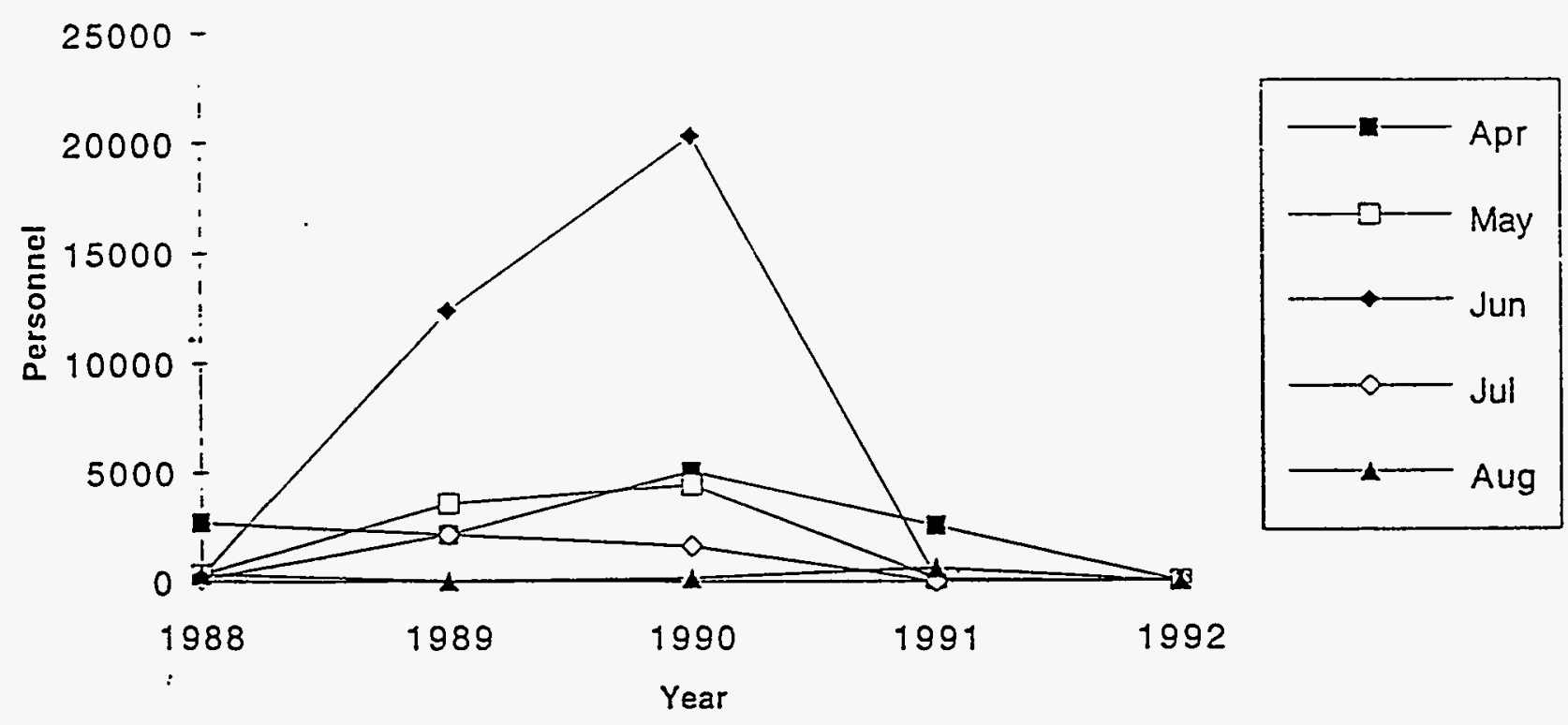

TA 13 A/ TA 13 B/ TA $13 C$

Wheel Vehicle

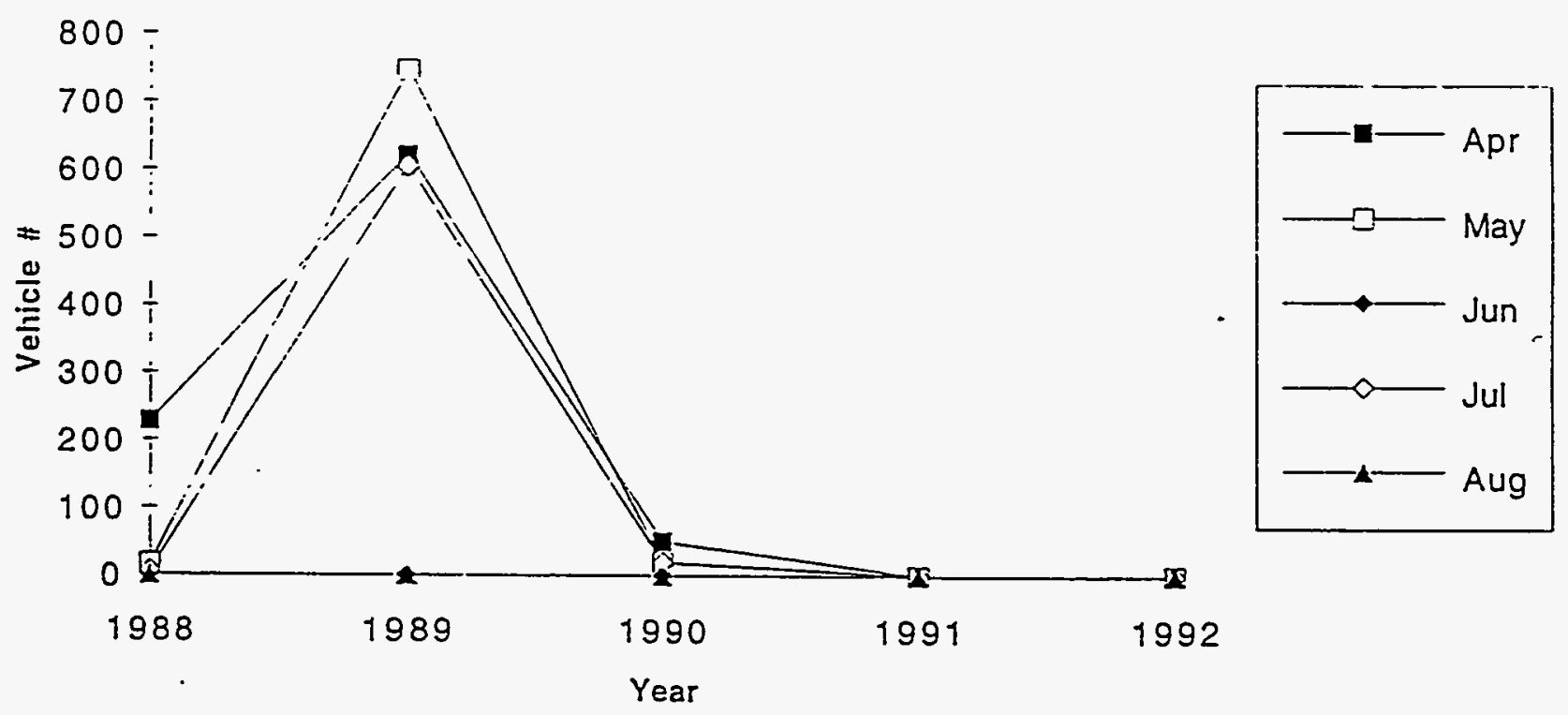

Figure 3.5. (contd) 
TA 13 A/ TA 13 B/ TA 13C

\section{Track Vehicle}

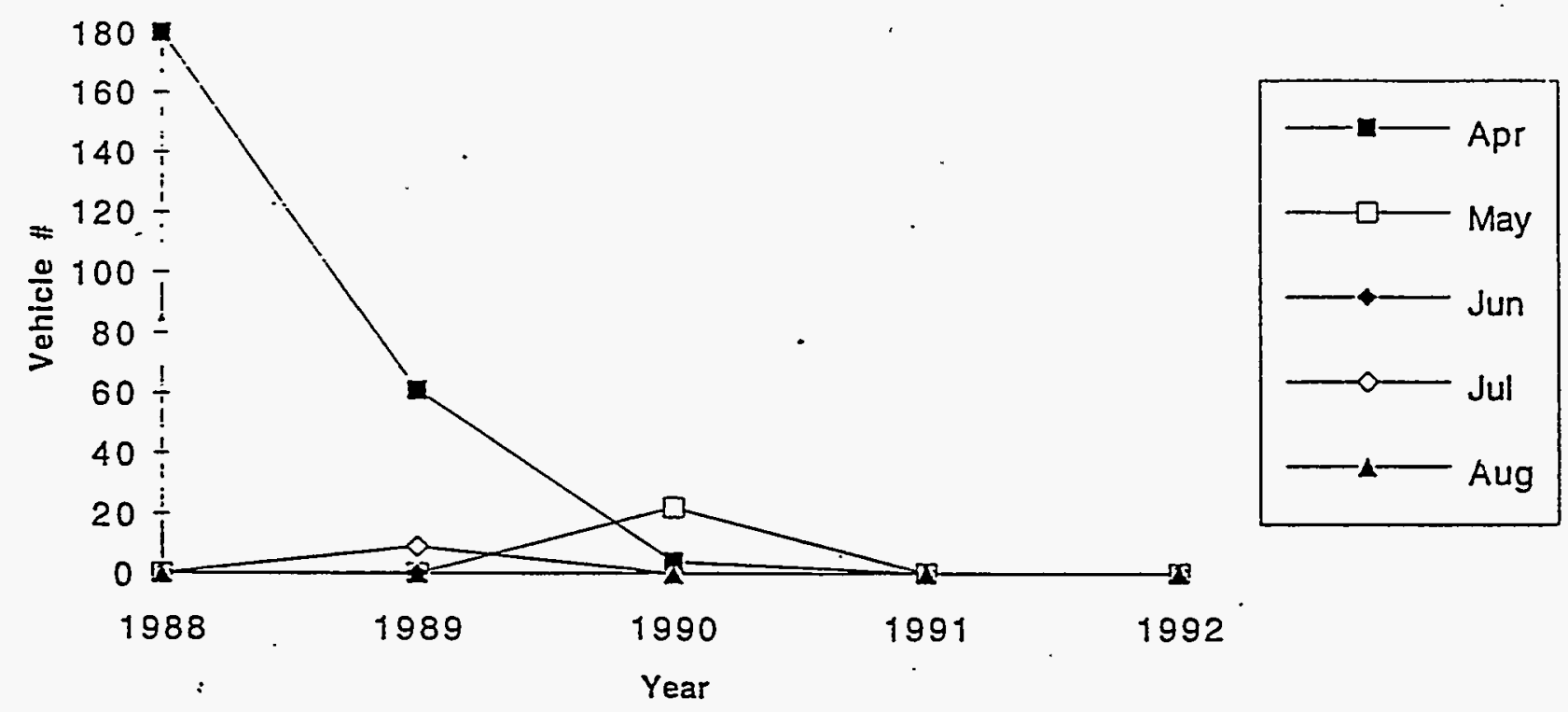

TA 13 A/ TA 13 B/ TA $13 C$

Personnel Dispatch

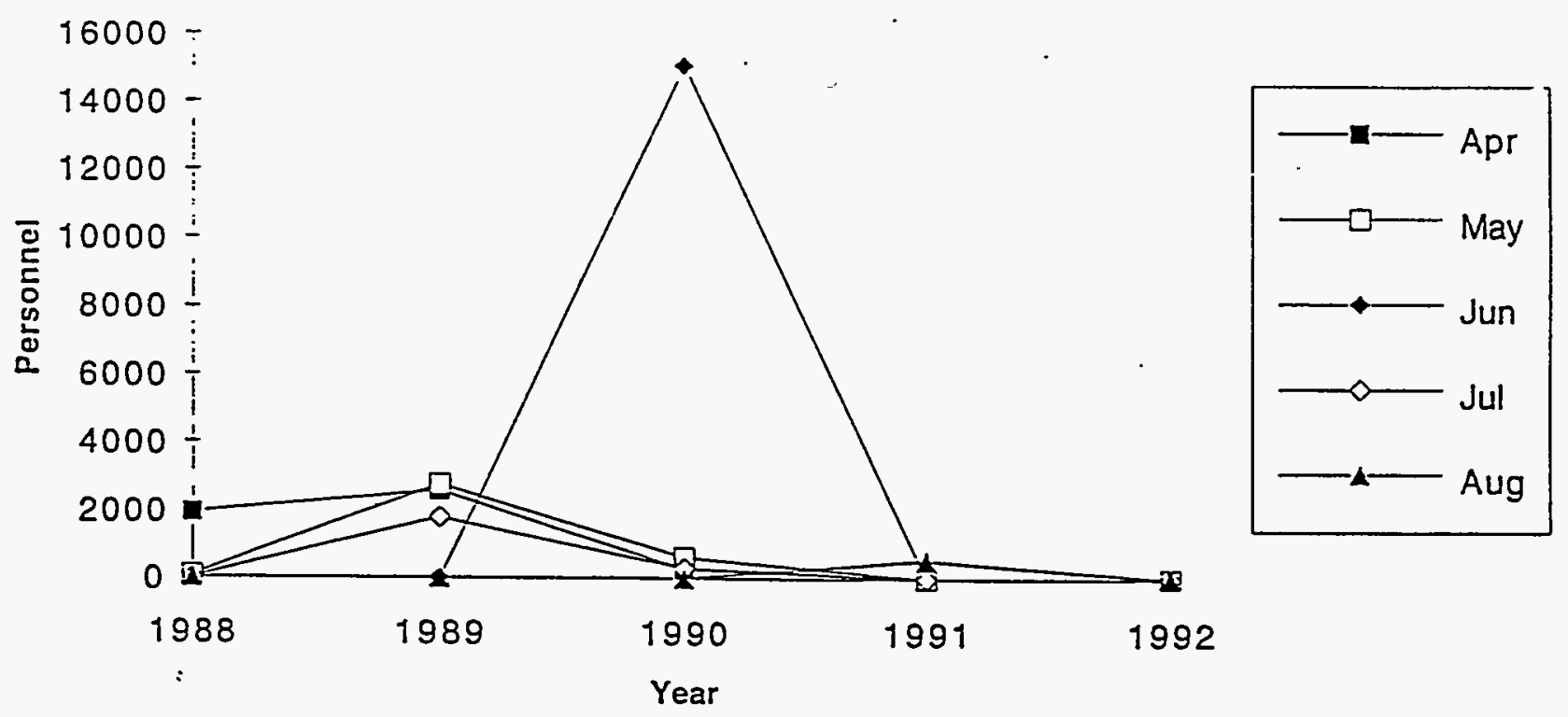

Figure 3.5. (contd) 
Table 3.4. Training Activities (wheel vehicles, track vehicles, and personnel) in Training Areas of Yakima Training Center, 1988-1992

\section{Training Areas \\ and Months}

TA $1 B / T A 1 A$

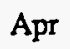

May

Jun

Jul

Aug

TA 1B/TA 1A

Apr

May

Jun

Jul

Aug

TA 1A/TA IB

Apr

May

Jun

Jul

Aug

TA 2A/TA 2B

TA 3A/TA 3B

Apr

May

Jun

Jul

Aug

TA 2A/TA $2 B$

TA 3A/TA 3B

Apr

May

Jun

Jul

Aug

TA 2A/TA 2B

TA 3A/TA 3B

$\begin{array}{lr}\text { Apr } & 5429 \\ \text { May } & 514 \\ \text { Jun } & 2467 \\ \text { Jul } & 720 \\ \text { Aug } & 1540\end{array}$

1988

89

150

178

234

68

32

0

84

0

14

497

1656

539

612

272

951

121

362

238

349

282

0

0

7

139

1540
1989

1990

1991

1992

Wheel Vehicles

767
711
2004
832
879

Track Vehicles

154
4
784
54
0

Personnel

4045

2188

7595

2677

1675

Wheel Vehicles

2841

1974

2759

2921

725

Track Vehicles

2434

455

1317

365

49

3067

1901

10556

902

90

174

119

517

2654
134

134

0

0

$\begin{array}{ll}7 & 0 \\ 0 & 0 \\ 0 & 0 \\ 0 & 0 \\ 0 & 0\end{array}$

213

0

0

0

$\begin{array}{rr}200 & 141 \\ 137 & 0 \\ 328 & 0 \\ 189 & 0 \\ 123 & 0\end{array}$

141

0

0

Vehicles

$$
\begin{array}{r}
300 \\
185 \\
1228 \\
197
\end{array}
$$

20
345
179
0
0

Personnel

13947
7502
9898
9963
5066

13202

3055

28663

2483

142 
Training Areas and Months

TA $10 \mathrm{~B} / 10 \mathrm{C}$

TA $11 \mathrm{~A} / 11 \mathrm{C}$

Apr

May

Jun

Jul

Aug

TA $10 \mathrm{~B} / 10 \mathrm{C}$

TA $11 \mathrm{~A} / 11 \mathrm{C}$

Apr

May

Jun

Jul

Aug

TA $10 \mathrm{~B} / 10 \mathrm{C}$

TA $11 \mathrm{~A} / 11 \mathrm{C}$

Apr

May

Jun

Jul

Aug

TA 13 A,B,C

Apr

May

Jun

Jul

Aug

TA 13 A,B,C

Apr

May

Jun

Jul

Aug

TA 13 A,B,C

Apr

May

Jun

Jul

Aug
Table 3.4. (contd)

1989

$\underline{1990}$

1991

1992

Wheel Vehicles
336

34

55

25

38

0

0

0

1

2691

305

232

91

325

228

17

0

6

0

180

0

0

0

0
625

1041

2104

525

2

Track Vehicles

24
0
1762
$\cdot 103$
0

Personnel

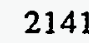

3564

12380

2159

55

Wheel Vehicles

$\begin{array}{rr}621 & 52 \\ 746 & 20 \\ 0 & 0 \\ 604 & 20 \\ 0 & 0\end{array}$

Track Vehicles

$$
\begin{array}{r}
61 \\
0 \\
0 \\
9 \\
0
\end{array}
$$

120

260

0

0

007
452

89

41

26

12

14

35

5015

4395

20292

1604

\begin{tabular}{|c|c|c|}
\hline \multicolumn{2}{|c|}{4} & \\
\hline & 22 & \\
\hline & 0 & \\
\hline & 0 & \\
\hline & 0 & \\
\hline
\end{tabular}

164

$\begin{array}{ll}3 & 0 \\ 0 & 0 \\ 0 & 0 \\ 0 & 0 \\ 0 & 0\end{array}$

$\begin{array}{rl}2557 & 0 \\ 165 & 0 \\ 131 . & 0 \\ 28 & 0 \\ 638 & 0\end{array}$

0

0

0

0

0

0

Personnel

1947
76
0
12
0

2576

2763

0

1788

0 
- Site 3 is proximal to Training Areas $1 \mathrm{~A}$ and $1 \mathrm{~B}$. Training activity in these areas has, generally, decreased since 1989 (Figure 3.5). Peak use of wheel and track vehicles was reported for 1989 for all months, with the greatest number reported for June $(2,004)$ (Table 3.4$)$. The greatest number of user days was reported for June $1990(10,556)$ (Table 3.4).

- Site 4 is proximal to Training Areas 13A, 13B, and 13C. Training activity in these areas has decreased since 1989 (Figure 3.5). Peak use of wheel vehicles for all months was reported for 1989, with a sharp decline following that period. Track vehicle use of these units declined sharply after 1988. The number of user days for these areas is generally low, with peak numbers $(15,072)$ reported for June 1990 (Table 3.4).

\subsection{Occurrence and Index to Abundance of Prey Species, Vegetation, and Disturbance Within Small Mammal Trap Sites}

\subsubsection{Prey Species Occurrence}

Locations of small mammal trap sites are listed in Table 2.2 and shown in Figure 3.6. Trap sites were randomly selected from UTM coordinates generated for the YTC. The occurrence of mammal holes and estimated density of animals per site are listed in Table 3.5. Species composition of small mammals and number are reported for each site for June, July, and August 1993 in Table 3.6. Species captured most commonly included deer mouse (Peromyscus maniculatus), least chipmunk (Eutamias minimum), and Great Basin pocket mouse (Perognathus parvus). The North Bivouac and Training Area 8B trap sites were characterized by a greater number of species and number of small mammals (see Table 3.6). This was observed consistently during June through August. Although fewer individuals were captured compared to the North Bivouac and Training Area 8B, the number of species at the Silica site and Range 55 was similarly elevated. Sites where species diversity and number of individuals captured was consistently low included the Beller Drop Zone and Training Area 9B. The Hanson Creek trap site represented an anomaly, where the number of individuals captured was generally similar to the Silica site and Range 55 (moderate) but species diversity was low. Variation among sites in prey species diversity and abundance may be related to disturbance and to vegetative characteristics of the site that will be discussed later.

Traps were checked twice daily between approximately 0600 and 0900 and 1700 and 2000 hours and reset to assess nocturnal and diumal species occurrence. Of the total captures of deer mice, nearly all $(98 \% ; n=131)$ were recorded between 0600 and 0900 . Similarly, the greatest number of Great Basin pocket mice were recorded between 0600 and $0900(98 \% ; n=73)$, indicating that both this species and deer mice are generally noctumal. Least chipmunks were collected in greater abundance during 1700 to 2000 hours (see Table 3.7).

\subsubsection{Index to Abundance of Small Mammals}

Mammal holes were classified as small $(0-3 \mathrm{~cm})$, medium $(3-6 \mathrm{~cm})$, and large $(>6 \mathrm{~cm})$ for purposes of providing an index to abundance of small, medium, and large mammals (see Table 3.5). For purposes of analysis, we assumed that small mammal holes represented use by deer mice, sagebrush voles (Lagurus curtatus), and Great Basin pocket mice; medium holes represented use by least chipmunk; and large holes represented use by Townsend's ground squirrel (Cittellus townsendii). Hole size is assumed to correspond to the body size of each species identified (Burt and Grosenheider 1976). The index was used to calculate population density on a per-unit-area basis for each trap site. 



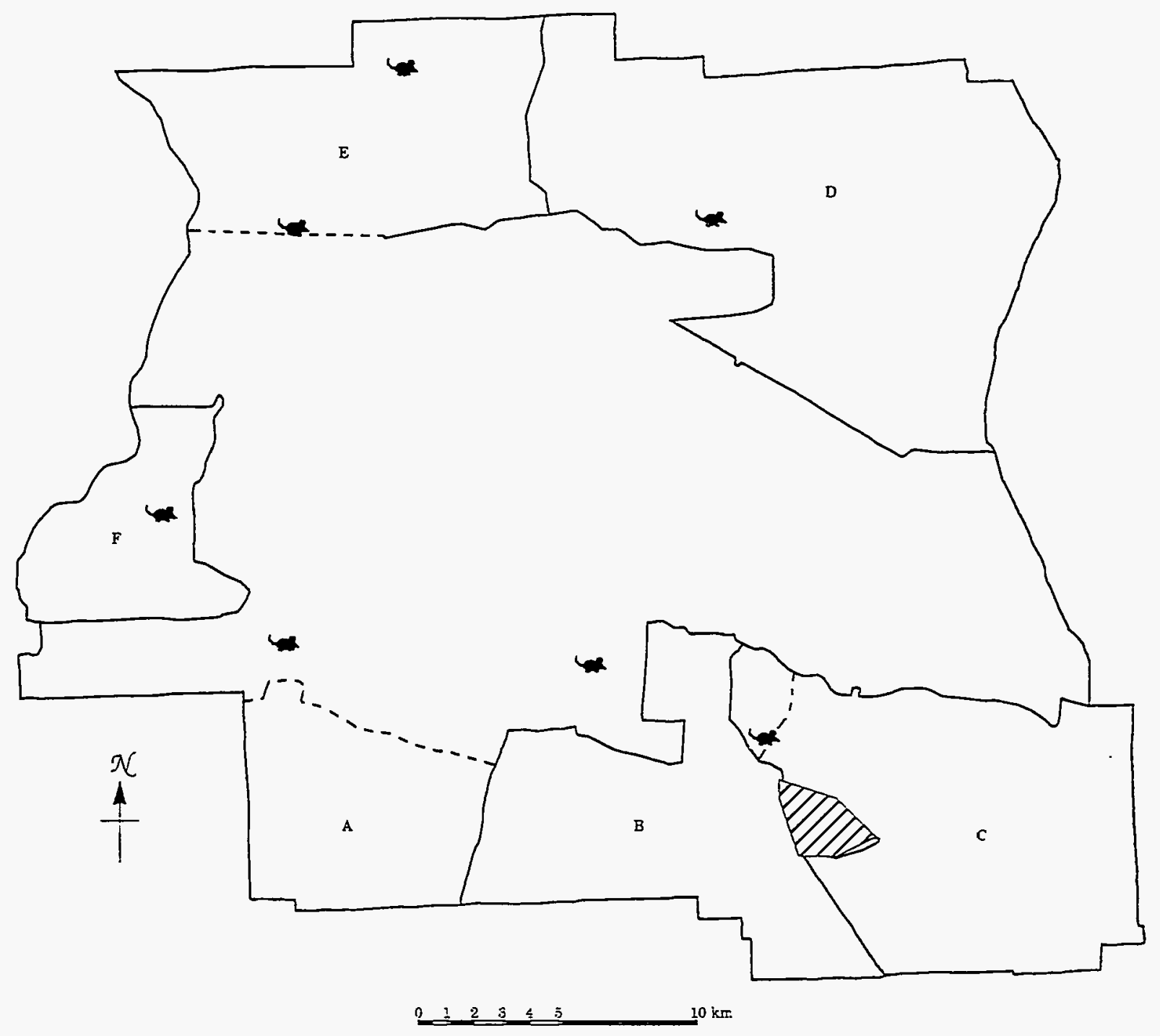

4. -Trap site

-..- -Fence

Figure 3.6. Small Mammal Trap Sites in Relation to Grazing Units, Yakima Training Center (Blank area in interior is not grazed.) 

Table 3.5. Frequency of Occurrence and Estimated Abundance of Small, Medium, and Large Mammal Holes at Seven Trap Sites, Yakima Training Center, 1993

Northing/Easting

Beller Drop Zone

Small

Medium

Large

Silica Site

Small

Medium

Large

Training Area 9B

Small

Medium

Large

North Bivouac

Small

Medium

Large

Hanson Creek

Small

Medium

Large

Training Area 8B

Small

Medium

Large

Range 55

Small

Medium

Large

Coordinates

5175799

700612

5186358

705532

5171130

705472

5191894

709586

5186511

720829

5167337

720249

5170437

716406
196

46

9

58

60

27

415

104

28

166

31

103.8

19.4

317

198.1

193.8

66.0

310

31.3

64.6

50
34.6

6.5

41.0

9.6

1.9

12.0

12.5

5.6

86.5

$\begin{array}{rr}65.0 & 21.7 \\ 17.5 & 5.8\end{array}$

$\begin{array}{rr}65.0 & 21.7 \\ 17.5 & 5.8\end{array}$

--

$\begin{array}{rrr}312 & 195.0 & 65.0 \\ 40 & 25.0 & 8.3 \\ 5 & 3.1 & 1.0\end{array}$


Table 3.6. Species Diversity of Small Mammals Collected June through August, Yakima Training Center, 1993

\begin{tabular}{|c|c|c|c|c|c|c|}
\hline Trap Site & $\begin{array}{l}\text { Species } \\
\text { Captured }\end{array}$ & Species & $\begin{array}{l}\text { June } \\
\text { Total }\end{array}$ & $\begin{array}{c}\text { July } \\
\text { Total } \\
\end{array}$ & $\begin{array}{l}\text { August } \\
\text { Total } \\
\end{array}$ & Total \\
\hline Beller & 2 & $\begin{array}{l}\text { Cittellus townsendii } \\
\text { Peromyscus maniculatus }\end{array}$ & $\begin{array}{l}1 \\
1\end{array}$ & & 2 & 4 \\
\hline Silica Site & 4 & $\begin{array}{l}\text { Peromyscus maniculatus } \\
\text { Eutamias minimum } \\
\text { Cittellus townsendii } \\
\text { Perognathus parvus }\end{array}$ & $\begin{array}{l}1 \\
1 \\
1\end{array}$ & $\begin{array}{l}3 \\
3 \\
5\end{array}$ & $\begin{array}{l}5 \\
1\end{array}$ & 20 \\
\hline Training Area 9B & 2 & $\begin{array}{l}\text { Peromyscus maniculatus } \\
\text { Perognathus parvus }\end{array}$ & & 1 & 1 & 2 \\
\hline North Bivouac & 5 & $\begin{array}{l}\text { Peromyscus maniculatus } \\
\text { Eutamias minimum } \\
\text { Cittellus townsendii } \\
\text { Lagurus curtatus } \\
\text { Perognathus parvus }\end{array}$ & $\begin{array}{r}11 \\
8 \\
. \quad 3 \\
1\end{array}$ & $\begin{array}{r}28 \\
21 \\
1 \\
6 \\
2\end{array}$ & $\begin{array}{r}22 \\
28 \\
6\end{array}$ & 137 \\
\hline Hanson Creek & 2 & $\begin{array}{l}\text { Perognathus parvus } \\
\text { Peromyscus maniculatus }\end{array}$ & & 16 & $\begin{array}{r}31 \\
1\end{array}$ & 48 \\
\hline Training Area 8B & 6 & $\begin{array}{l}\text { Eutamias minimum } \\
\text { Cittellus townsendii } \\
\text { Peromyscus maniculatus } \\
\text { Lagurus curtatus } \\
\text { Perognathus parvus } \\
\text { Reithrodontomys megalotis }\end{array}$ & $\begin{array}{r}16 \\
1 \\
1 \\
1 \\
\end{array}$ & $\begin{array}{r}13 \\
9 \\
22 \\
3 \\
5\end{array}$ & $\begin{array}{r}27 \\
25 \\
3 \\
4 \\
1\end{array}$ & 131 \\
\hline Range 55 & 4 & $\begin{array}{l}\text { Peromyscus maniculatus } \\
\text { Lagurus curtatus } \\
\text { Cittellus townsendii } \\
\text { Perognathus parvus }\end{array}$ & 1 & $\begin{array}{l}4 \\
2 \\
1\end{array}$ & $\begin{array}{r}8 \\
11 \\
13\end{array}$ & 40 \\
\hline
\end{tabular}

Table 3.7. Occurrence of Small Mammals Captured During Diurnal and Noctumal Trapping Sessions, Yakima Training Center, June through August 1993

\begin{tabular}{l}
\multicolumn{1}{c}{ Species } \\
\hline Peromyscus maniculatus \\
Eutamias minimum \\
Perognatus parvus \\
Lagurus curtatus \\
Cittellus townsendii
\end{tabular}

\begin{tabular}{cc}
$\begin{array}{c}\text { Traps checked, } \\
0600-0900 \mathrm{~h}\end{array}$ & $\begin{array}{c}\text { Traps checked, } \\
1700-2000 \mathrm{~h}\end{array}$ \\
\cline { 3 - 3 } & \\
123 & 8 \\
50 & 72 \\
69 & 4 \\
19 & 14 \\
4 & 13
\end{tabular}


Based on Kelker's method for calculating density and applying our index and the assumption that each individual animal is represented by three holes, it appears that small-sized mammals represent the majority the mammal species on the YTC. Further, it appears that the North Bivouac and Training Area 8B trap sites have a greater population density of mammals than the other sites. Although this result is based on several gross assumptions, it is consistent with trapping success for these sites. The sites do differ, however, in the ratio of small- to medium-sized animals estimated. The North Bivouac site is characterized by a greater percentage of small-sized mammals estimated for the site (76\%), whereas Training Area $8 \mathrm{~B}$ has equal percentages of small- and medium-sized mammals estimated for the site ( $46 \%$ and $47 \%$, respectively). This result is also consistent with trapping success for these sites. Sites where the estimated density was low include Training Area 9B and Hanson Creek (see Table 3.5). Although the number of holes would suggest that an equal ratio of small- to medium-sized mammals (e.g., $40 \%$ to $42 \%$, respectively) should occur at Training Area 9B, no medium-sized mammals were captured at that site (see Table 3.6). It should be noted that both of these sites were characterized by low species diversity, with only two species (deer mice and Great Basin pocket mice) captured.

\subsubsection{Vegetation Distribution}

Primary vegetation species occurring at small mammal trap sites included bluebunch wheatgrass, Sandberg's bluegrass, cheatgrass, and big sagebrush (see Table 3.8). Although big sagebrush was recorded relatively frequently in the Daubenmire plots, the percent cover of big sagebrush recorded using this method should not be construed to be representative of the percent cover for the species, as Daubenmire noted that large erratically distributed plants (e.g., shrubs) are not sampled with a high degree of accuracy using this method. Tumble mustard and bottlebrush squirreltail (Sitanion hystrix) were also recorded frequently at the trap sites.

Bluebunch wheatgrass and Sandberg's bluegrass were the dominant species occurring at the trap sites. Training Area 8B and the Silica trap sites had characteristically less canopy cover of bluebunch wheatgrass and Sandberg's bluegrass combined than did the other sites $(19.2 \%$ and $24.5 \%$, respectively); however, the other sites did have a greater percentage of big sagebrush. This result is consistent with estimates of canopy cover of big sagebrush measured within 10- x 10-m shrub plots at these sites (22.8\% and $22.6 \%$, respectively) (see Table 3.9). With exception for the North Bivouac trap site, all sites were characterized by greater than $40 \%$ bare ground.

The dominant shrub species occurring among the trap sites included big sagebrush, green rabbitbrush, and gray rabbitbrush (Table 3.10). Total shrub stems ranged between 7 and 499 among the sites. The Beller Drop Zone and North Bivouac trap sites had a greater number of stems relative to the other trap sites; however, the Silica site and Hanson Creek also had a relatively high number of stems (Table 3.10). Further, the North Bivouac trap site had a greater number of shrub species than other sites.

Mean diameter and height for each species recorded at each trap site are included in Table 3.10. Fifty-five percent of shrubs ranged between 52 and $100 \mathrm{~cm}$ mean diameter although shrub diameter varied among the sites. Mean shrub height ranged between 17 and $56 \mathrm{~cm}$, the majority of stems $(78 \%)$ ranging between 17 and $36 \mathrm{~cm}$. Overall, shrub height and diameter suggest that plants are small in stature and possibly young. 
Table 3.8. Percent of Canopy Cover of Frequently Occurring Vegetation Species and Bare Ground of Small Mammal Trap Sites on the Yakima Training Center, June through August 1993

\begin{tabular}{|c|c|c|c|c|c|c|c|}
\hline Species & Beller & $\begin{array}{l}\text { Silica } \\
\text { Site } \\
\end{array}$ & $\begin{array}{l}\mathrm{TA} \\
9 \mathrm{~B} \\
\end{array}$ & $\begin{array}{c}\text { North } \\
\text { Bivouac }\end{array}$ & $\begin{array}{c}\text { Hanson } \\
\text { Creek }\end{array}$ & $\begin{array}{l}\mathrm{TA} \\
8 \mathrm{~B} \\
\end{array}$ & $\begin{array}{c}\text { Range } \\
55 \\
\end{array}$ \\
\hline Agropyron spicatum & 9.6 & 14.0 & 21.3 & 15.6 & 7.0 & 4.9 & 39.3 \\
\hline Poa sandbergii & 20.9 & 10.5 & 8.4 & 21.4 & 24.3 & 14.3 & 22.8 \\
\hline Bromus tectorum & 1.6 & 2.1 & 1.9 & 0.9 & -- & 2.4 & 0.5 \\
\hline Artemisia tridentata & 6.3 & 23.0 & $-\cdots$ & 1.5 & 4.5 & 13.0 & -- \\
\hline Sisymbrium altissimum & 0.3 & 1.0 & 0.1 & -- & -- & - & 3.3 \\
\hline Sitanion hystrix & -- & 10.6 & 2.6 & 3.1 & -- & -- & 2.0 \\
\hline Bare ground & 48.9 & 42.3 & 44.5 & 25.9 & 62.9 & 50.4 & 57.1 \\
\hline
\end{tabular}

Table 3.9. Percent of Canopy Cover of Shrub Species at Small Mammal Trap Sites, Yakima Training Center, 1993

\begin{tabular}{|c|c|c|c|c|c|c|c|}
\hline Species & Beller & $\begin{array}{c}\text { Silica } \\
\text { Site } \\
\end{array}$ & $\begin{array}{l}\text { TA } \\
9 \mathrm{~B}\end{array}$ & $\begin{array}{l}\text { North } \\
\text { Bivouac }\end{array}$ & $\begin{array}{c}\text { Hanson } \\
\text { Creek }\end{array}$ & $\begin{array}{r}\mathrm{TA} \\
8 \mathrm{~B} \\
\end{array}$ & $\begin{array}{c}\text { Range } \\
55 \\
\end{array}$ \\
\hline Artemisia tridentata & 6.0 & 22.6 & -- & 8.0 & 6.7 & 22.8 & -- \\
\hline Chrysothamnus nauseosus & 1.6 & -- & -- & 2.9 & -- & -- & 0.4 \\
\hline Chrysothamnus vicidiflorus & 0.1 & 0.1 & 0.4 & 6.8 & -- & -- & 0.2 \\
\hline Artemisia tripartita & -- & -- & -- & 0.6 & 10.4 & -- & -- \\
\hline Tetradymia canescens & -- & -- & 3.2 & -. & -- & -- & -- \\
\hline Grayia spinosa & -- & -- & -- & -- & 0.6 & -- & -- \\
\hline Total & 7.7 & 22.7 & 3.6 & 18.3 & 17.7 & 22.8 & 0.6 \\
\hline
\end{tabular}

Based on the estimation of Loetsch et al. (1973) of area and our recorded stem density from 10- x 10-m quadrats, the percent cover can be obtained as follows:

$$
\mathrm{C}=100 \mathrm{AD}
$$

where $\mathrm{C}=\operatorname{cover}(\%)$

$A=$ mean area per plant (area)

$\mathrm{D}=$ density of plants (number per unit area, where the area units are the same as area for $\mathrm{A}$ ).

Canopy cover was determined for each species at each trap site (see Table 3.9). Because all stems were counted within the $400-\mathrm{m}^{2}$ sample area, it is assumed that the sample area represents the general character of each site. Big sagebrush dominated the canopy on all sites where it occurred, with the exception of the Hanson Creek trap site where three-tip sage was the dominant species. Overall, canopy cover was lowest at the Beller Drop Zone, Training Area 9B, and Range 55 trap sites. Training Area $8 \mathrm{~B}$ and the Silica trap sites had the greatest canopy cover (22.8\% and $22.7 \%$, respectively) but were not significantly different from the North Bivouac and Hanson Creek trap sites (18.3\% and $17.7 \%$, respectively). Although the greatest total stem density was recorded at the Beller Drop Zone, the percent cover of vegetation, primarily big sagebrush, was generally lower in comparison to the other sites, which suggests that plants are smaller-statured and perhaps young. On the hand, the 
Table 3.10. Number of Stems, Diameter $(\mathrm{dm})$, and Height (hgt) (units $=\mathrm{cm}$ ) Recorded at Small Mammal Trap Sites, Yakima Training Center, June through August 1993

\begin{tabular}{|c|c|c|c|c|c|c|c|c|c|c|c|c|c|c|c|}
\hline \multirow[t]{2}{*}{ Species } & & \multicolumn{2}{|c|}{ Beller } & \multicolumn{2}{|c|}{$\begin{array}{c}\text { Silica } \\
\text { Site } \\
\end{array}$} & \multicolumn{2}{|c|}{$\begin{array}{l}\mathrm{TA} \\
9 \mathrm{~B} \\
\end{array}$} & \multicolumn{2}{|c|}{$\begin{array}{c}\text { North } \\
\text { Bivouac }\end{array}$} & \multicolumn{2}{|c|}{$\begin{array}{c}\text { Hanson } \\
\text { Creek }\end{array}$} & \multicolumn{2}{|c|}{$\begin{array}{r}\mathrm{TA} \\
8 \mathrm{~B} \\
\end{array}$} & \multicolumn{2}{|c|}{$\begin{array}{c}\text { Range } \\
55 \\
\end{array}$} \\
\hline & & dm & hgt & $\mathrm{dm}$ & $\underline{\text { hgt }}$ & $\mathrm{dm}$ & $\underline{\text { hgt }}$ & $\underline{\mathrm{dm}}$ & hgt & dm & $\underline{\mathrm{hgt}}$ & $\underline{\mathrm{dm}}$ & $\underline{\text { hgt }}$ & $\mathrm{dm}$ & $\underline{\text { hgt }}$ \\
\hline Artemisia & $\overline{\mathbf{x}}$ & 30 & 29 & 62 & 35 & - & - & 62 & 47 & 67 & 40 & 95 & 52 & - & - \\
\hline tridentata & $\mathbf{n}$ & 352 & & 300 & & - & & 108 & & 76 & & 129 & & - & \\
\hline Chrysothamnus & $\overline{\mathrm{x}}$ & 25 & 2 & - & - & - & - & 93 & 56 & - & - & - & - & 100 & 46 \\
\hline nauseosus & $\mathbf{n}$ & 133 & & - & & - & & 17 & & - & & - & & 2 & \\
\hline Chrysothamnus & $\overline{\mathbf{x}}$ & 23 & 17 & 52 & 35 & 71 & 39 & 43 & 24 & - & - & - & - & 96 & 38 \\
\hline viscidiflorus & $\mathbf{n}$ & 14 & & 1 & & 4 & & 188 & & - & & - & & 1 & \\
\hline Artemisia & $\overline{\mathrm{x}}$ & - & - & - & - & - & - & 87 & 45 & 56 & 28 & -- & - & - & - \\
\hline tripartita & $\mathrm{n}$ & & & & & & & $\cdot 4$ & & 169 & & & & & \\
\hline Tetradymia & $\overline{\mathbf{x}}$ & - & - & - & - & 69 & 33 & - & - & - & - & - & - & - & - \\
\hline canescens & $\mathrm{n}$ & - & & - & & 34 & & - & & - & & - & & - & \\
\hline Grayia & $\overline{\mathbf{x}}$ & - & - & - & - & - & - & - & - & 63 & 39 & -- & - & - & - \\
\hline spinosa & $\mathrm{n}$ & - & & - & & - & & - & & 8 & & - & & - & \\
\hline Stems $/ 400 \mathrm{~m}^{2}$ & & 499 & & 301 & & 38 & & 317 & & 253 & & 129 & & 3 & \\
\hline
\end{tabular}

Silica and North Bivouac trap sites have relatively high stem densities and percent cover. It should be noted, however, that the North Bivouac trap site has a greater number of species present than the Silica site.

\subsubsection{Disturbance}

Disturbance at each trap site was measured within five $10-\mathrm{x} 10$-m quadrats located at equal intervals along each $100-\mathrm{m}$ vegetation transect $(n=10)$. Disturbance was noted as evidence of track vehicles, wheel vehicles, human debris, disturbed vegetation (e.g., broken sagebrush), cheatgrass/ knapweed, cattle grazing, fire, and/or ordnance (see Table 3.11). The predominant types of disturbance (e.g., disturbance that was noted at a majority of the trap sites) evidenced presence of wheel vehicles, track vehicles, human debris, and cattle grazing. Cattle grazing was noted at all of the trap sites and recorded most frequently at Hanson Creek and the North Bivouac trap sites, which were located within Grazing Units D and E, respectively (see Figure 3.2). Since 1988, grazing intensity in Unit D has remained relatively constant at approximately 400 to 500 AUMs (see Table 3.3). However, in Unit $\mathrm{E}$ grazing has been curtailed since 1989, the monthly maximum decreasing from 
Table 3.11. Type and Frequency of Disturbance (as indicated by "hits") at Small Mammal Trap Sites, Yakima Training Center, 1993

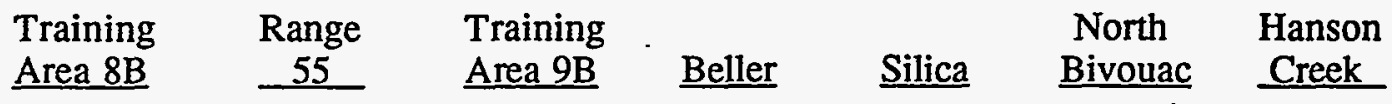

$\begin{array}{lccccccc}\begin{array}{l}\text { Track } \\ \text { vehicles }\end{array} & 7 & 6 & 4 & 12 & 10 & 0 & 0 \\ \begin{array}{l}\text { Wheel } \\ \text { vehicles }\end{array} & 7 & 4 & 9 & 8 & 0 & 0 & 1 \\ \begin{array}{l}\text { Human } \\ \text { debris }\end{array} & 8 & 1 & 5 & 5 & 2 & 0 & 2 \\ \begin{array}{l}\text { Disturbed } \\ \text { vegetation }\end{array} & 2 & 1 & 0 & 8 & 4 & 0 & 0 \\ \begin{array}{l}\text { Cheatgrass/ } \\ \text { knapweed }\end{array} & 0 & 10 & 10 & 0 & 0 & 0 & 0 \\ \begin{array}{l}\text { Cattle } \\ \text { grazing }\end{array} & 6 & 3 & 2 & 5 & 6 & 9 & 10 \\ \text { Fire } & 0 & 1 & 0 & 0 & 0 & 0 & 0 \\ \text { Ordnance } & 0 & 7 & 0 & 0 & 1 & 0 & 0\end{array}$

nearly 700 AUMs in May 1989 to 125 in May 1992. This observation may be of significance relative to vegetation composition and relative abundance of small mammals at these sites. The Hanson Creek trap site has a greater percentage of bare ground than the North Bivouac trap site (62.9\% versus $25.9 \%$, respectively); and, as was noted previously, the North Bivouac site is characterized by a greater number and diversity of small mammals than the Hanson Creek site (114 versus 41 animals/ha, respectively).

Evidence of track vehicles was noted more often at the Beller Drop Zone and the Silica site, than at any other site and was the most predominant type of disturbance at these sites. Both sites are located in Training Areas 1A and 3A, respectively. Use of track vehicles in the training areas has declined since 1989, with each area receiving the greatest use during 1989. It should be noted, however, that the number of track vehicles used on Training Area $1 \mathrm{~A}$ is approximately $50 \%$ greater than the number reported for Training Area 3A during 1989 (632 versus 335, respectively). The incidence of broken sagebrush (disturbed vegetation) was noted most frequently at the Beller Drop Zone (see Table 3.11).

Evidence of wheel vehicles was noted most frequently at Training Area 9B and the Beller Drop Zone. Use of wheel vehicles in the Beller Drop Zone has declined sharply since 1989, when use reported was 2,747. Wheel vehicular traffic in Training Area 9B has also declined since 1989, when peak use was reported at 1,451 vehicles. The greatest frequency of occurrence of disturbed vegetation for any of the sites occurred at the Beller Drop Zone (Table 3.11). Although Training Area $9 \mathrm{~B}$ is a restoration site, regenerated sagebrush was not recorded within randomly sampled plots. 
Human debris was noted at all trap sites, with the exception of the North Bivouac, and noted most frequently at Training Area 8B.

If one "hit" was noted each time a type of disturbance was counted at a given trap site, the Hanson Creek and North Bivouac trap sites would represent the "least disturbed" sites, and the Beller site would represent the "most disturbed." Because we did not rank the type of disturbance based on assumptions of potential impact to small mammal habitat, our measure merely provides a relative index of the types and frequency of disturbance evidenced at each trap site.

\subsection{Prey Species Selection of Pair of Nested Ferruginous Hawks}

We limited visits to the active ferruginous hawk nest to reduce the amount of disturbance to nested birds. Therefore, raptor castings collected at the nest site represent prey species selection for a period that included egg laying, incubation, rearing, and fledging young birds. Small mammal remains were identified in 53\% of all raptor castings, with less evidence of birds and insects and no trace of reptiles (Figure 3.7). Deer mice and sagebrush voles composed $72 \%$ of the small mammal remains in ferruginous hawk castings collected during 1993 . The remaining $28 \%$ of small mammal remains included other Cricetid rodents that occur on the YTC, e.g., the montane vole (Microtus montanus) and long-tailed vole ( $M$. longicaudus); and insectivores, e.g., Merriam's shrew (Sorex merriami) (see Table 3.6). Northern pocket gopher (Thomomys talpoides) and Townsend's ground squirrel occurred in $16 \%$ and $4 \%$, respectively, of raptor castings collected during 1993 (Figure 3.7). Figure 3.8 depicts the relative frequency of prey, including rabbit species, occurring in ferruginous hawk castings. Small mammals occurred with the greatest relative frequency (e.g., 53\%), with Leporids occurring in the second greatest frequency (31\%).

The relative frequency of small mammals that were identified in ferruginous hawk castings during 1993 is noteworthy in light of results of 1993 small mammal trapping efforts. The number of "large" mammals was reduced in comparison to small- and medium-sized mammals captured during 1993. The Leporidae represent a group of larger-sized mammals, the population density and distribution of which were not recorded during 1993 trapping efforts. Consequently, any estimates of availability of large prey species to ferruginous hawks would be suspect. It should be noted that the $31 \%$ frequency of occurrence of remains of this group of larger-sized mammals exceeds that recorded for mammals of slightly smaller size (e.g., Townsend's ground squirrel and northem pocket gopher, which both have a $20 \%$ frequency of occurrence). 


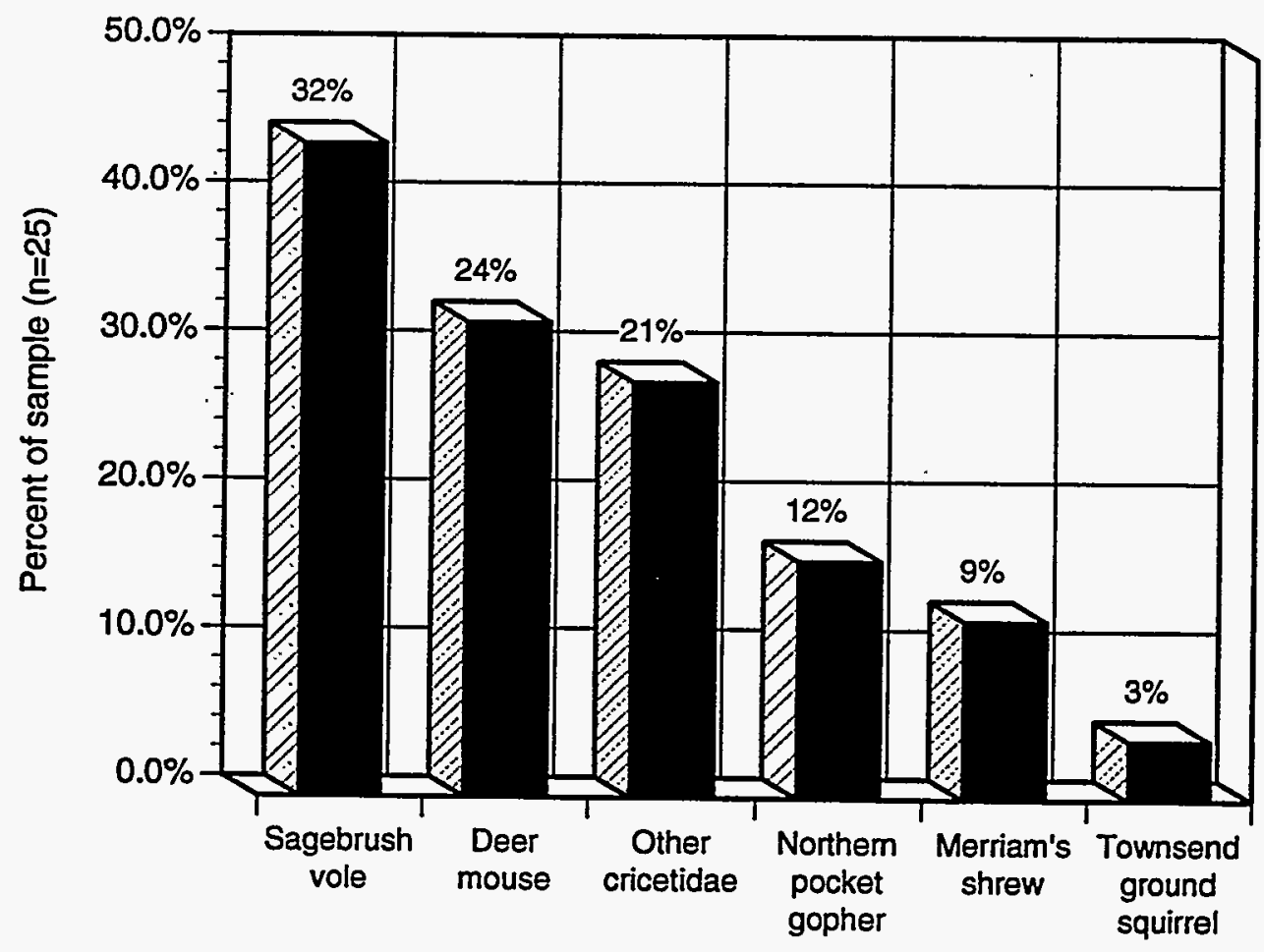

59403001.3

Figure 3.7. Frequency of Occurrence of Small Mammals in Diets of Ferruginous Hawks, Yakima Training Center, 1993
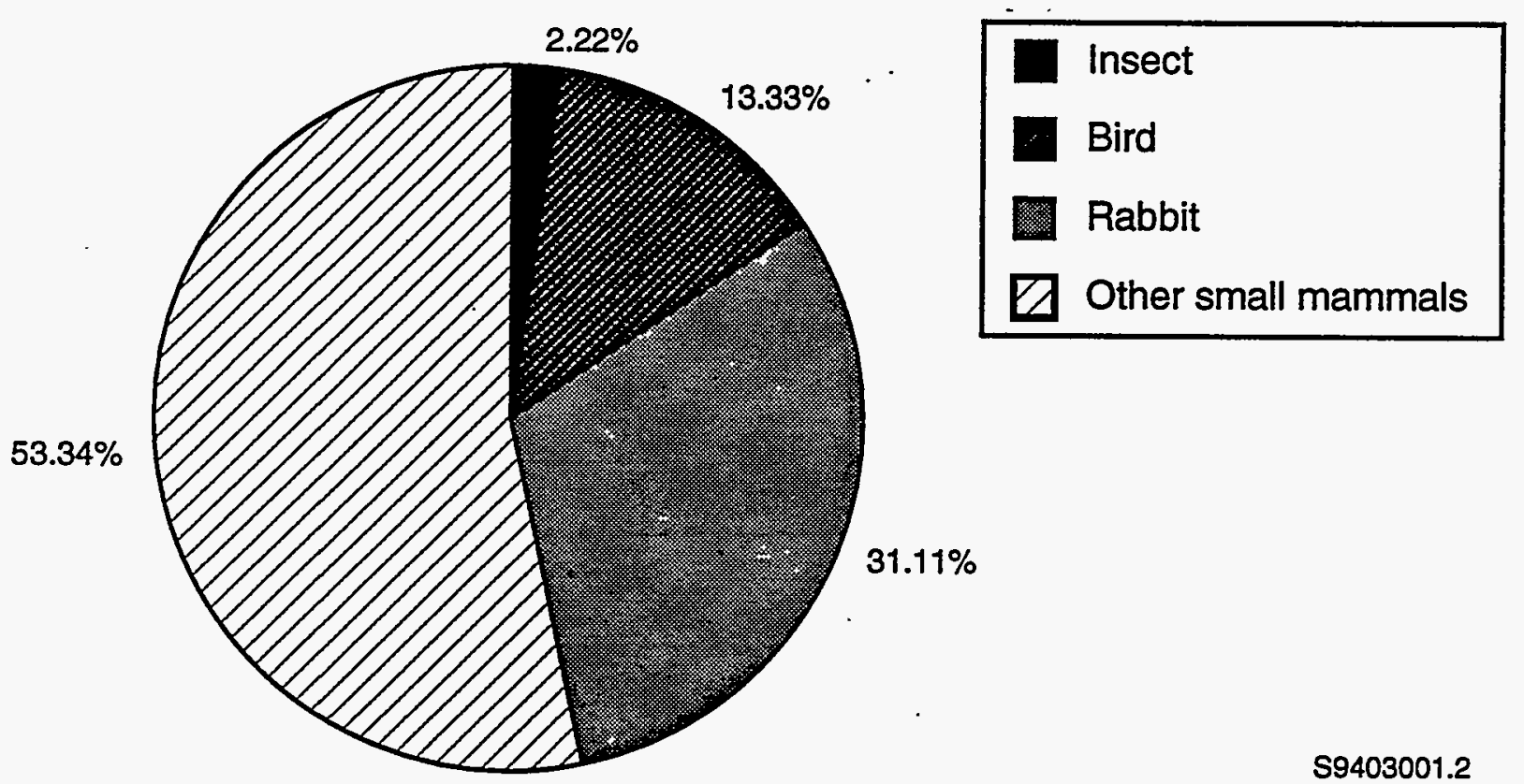

Figure 3.8. Frequency of Occurrence of Mammals, Reptiles, and Birds in Diets of Ferruginous Hawks, Yakima Training Center, 1993 


\subsection{Discussion and Conclusions}

To describe the status of ferruginous hawks on the YTC, the prey base and characteristics of prey species habitat (e.g., vegetative composition and disturbance) were sampled. The results, which are not intended to reflect a relationship between frequency of disturbance and trapping success, suggest that relationships between "types" and "frequency" of disturbance and small mammal and vegetation species distribution may exist. As the degree or type of disturbance affects small mammal populations, ultimately an effect on ferruginous hawks will be realized. Initial proposals to identify suitability of the YTC for placement of nest structures were redefined, as nest site availability did not appear to be a factor limiting ferruginous hawk use of YTC. It was concluded that analysis of prey species abundance and distribution and a general analysis of site disturbance would allow for analysis of ultimate factors that may affect site suitability for ferruginous hawks.

The Washington Department of Fish and Wildlife has maintained a consecutive record of use of YTC by ferruginous hawks for approximately 6 years. Use of YTC by ferruginous hawks has varied during the previous 6 years (see Table 2.1). Direct or indirect effects of disturbance on the species have not been defined. This report presents results of a survey of prey species composition and abundance, vegetation distribution, and disturbance at seven randomly located sites on the YTC. The results can be applied to questions specific to habitat management or restoration potential of YTC for ferruginous hawks or to questions regarding ultimate or proximate factors that may affect ferruginous hawks occurring on the YTC.

Disturbance, manifest as human use or habitat alteration, has been identified as a primary factor affecting ferruginous hawk production (Thurow et al. 1980). Porter and White (1977) concluded that direct human disturbance was the overriding negative factor to which ferruginous hawks did not adapt and that negative effects of human disturbance were augmented when prey availability was reduced. Others speculate that human activity, which may affect nest occupancy or alter nest site location, may not be as significant as habitat alteration, which affects the prey base and production of young (White and Thurow 1985).

Several studies (Thurow et al. 1980, Smith et al. 1981) have demonstrated that ferruginous hawks are strongly dependant on prey availability and closely cycle with fluctuations in populations of small mammals. Stalmaster (1985) observed a significantly high correlation between ferruginous hawk productivity and prey density. Similarly, Smith et al. (1981) demonstrated that decreased prey availability for ferruginous hawks in Utah caused birds to reduce the number of nest attempts, reduce clutch size, fail in attempts to rear young, and reduce hatch success. Because the number of active ferruginous hawk nests on YTC has varied in the recent past, prey species availability and site disturbance were examined.

Although fluctuations in prey species density are related to intrinsic population factors, prey species abundance and distribution has been related to habitat condition and overall suitability of habitat for a species (Woffinden 1975). Baker and Brooks (1981) observed that management of rough-legged hawks was possible by manipulating the vegetative component of the hawks' foraging habitat to reduce numbers of prey species. Raptors responded by decreasing use of the area. Land management activities that alter the density and structure of native vegetation can affect small mammal populations; however, some level of land conversion may be tolerable by prey species populations. Howard and Wolfe (1976) suggested that "ferruginous hawks benefit from areas managed for a high degree of interspersion of vegetation," as may be found in areas subject to some level of 
disturbance. To date, there are no quantitative assessments of the degree of habitat alteration that will allow ferruginous hawks to persist. Varying degrees of habitat alteration on YTC have resulted from land management for grazing and military maneuvers.

\subsection{Effects of Grazing on Yakima Training Center}

Overgrazing has been identified as one of the five ultimate causes of ferruginous hawk population decline, affecting the species by changing nest substrate, affecting prey abundance (Phillips 1939, Black and Frischknecht 1971), and affecting prey vulnerability (Kochert et al. 1986). Improper grazing contributes to a reduction of perennial grass species with replacement by annuals and woody species (Black and Frischknecht 1971). The Hanson Creek and North Bivouac sites have been subject to varying degrees of grazing pressure over the previous four years.

The North Bivouac and Hanson Creek sites, which were characterized as "least" disturbed, were typified by disturbance from cattle grazing. In the case of the North Bivouac site, cattle grazing was the only type of disturbance recorded. The Hanson Creek site is located in Grazing Unit D, which has been grazed since 1988 and has received relatively high grazing pressure during the previous 4 years. The North Bivouac site is located in Grazing Unit E, which has also been grazed since 1988. However, the AUMs in this unit were reduced during 1992, to less than 50\% of 1991 grazing levels (see Table 3.3). This is of significance relative to vegetation distribution and species composition of small mammals.

The Hanson Creek site was characterized by a low number of species and moderate trapping success ( $n=48$ captures for 375 trap nights) relative.to other trap sites. The species captured at the site included Great Basin pocket mice and one deer mouse. Indices of abundance to small mammals were low at the Hanson Creek site (41 animals/ha) compared to the North Bivouac site. The Hanson Creek site was characterized by $63 \%$ bare ground with moderate shrub stem density $\left(253 \mathrm{stems} / \mathrm{m}^{2}\right)$. Percent canopy cover of shrubs was moderate (18\% cover), and shrubs ranged between 28 and $40 \mathrm{~cm}$ in height. The dominant vegetative cover at the site was Sandberg's bluegrass (24\% cover).

The North Bivouac site, on the other hand, was characterized by a high number of species ( $n=$ 5) and high trapping success $(n=137)$ (see Table 3.6). Species trapped at the site included deer mice, Townsend's ground squirrel, sagebrush vole, Great Basin pocket mouse, and least chipmunk (see Table 3.6). Population estimates derived from indices of abundance were high (114 animals/ha). This site had the lowest percentage of bare ground (26\%) and was dominated by herbaceous bluebunch wheatgrass ( $16 \%$ cover) and Sandberg's bluegrass (21\% cover) (Table 3.8$)$. Shrub stem density at the site was relatively high $\left(317 \mathrm{shrubs} / 400 \mathrm{~m}^{2}\right)$ and included big sagebrush and green rabbitbrush (Table 3.10). Percent canopy cover of shrubs was moderate (18\% cover) (Table 3.9) and shrubs ranged between 24 and $56 \mathrm{~cm}$ in height (Table 3.10 ).

The notable difference between the North Bivouac and Hanson Creek sites is the percentage of bare ground (26\% versus 63\%, respectively) and the species complement of vegetation (Table 3.8). The sites occur within the A. tridentata/Agropyron spicatum association (Franklin and Dymess 1984). The species composition of this association includes shrubs (i.e., A. tridentata, $A$. tripartita, $C$. nauseosus, C. viscidiflorus, Grayia spinosa); grasses dominated by Agropyron, Stipa, Poa, or Sitanion; and an understory of Poa sandbergii, Bromus tectorum, and Lappula redowskii. The North Bivouac site retains a significant portion of this complement, including Agropyron, Artemisia, Poa, Bromus, Sitanion, and Chrysomthamnus (see Tables 3.8 and 3.9). The Hanson Creek site, on the other hand, retains remnants of this association including Agropyron, Poa, Artemisia, and Grayia. $P o a$, which is not significantly affected by grazing, is distributed similarly across both sites (24\% and 
21\% cover at Hanson Creek and North Bivouac sites, respectively). Agropyron, which is affected by grazing, occurs in $7 \%$ and $16 \%$ cover at the Hanson Creek and the North Bivouac sites, respectively (Table 3.8). Similar variation in occurrence of Bromus tectorum was also noted with the species absent from the Hanson Creek site and occurring in $0.9 \%$ cover at the North Bivouac site. Bromus tectorum generally increases as a result of grazing, the species re-establishing very slowly in this association after grazing has ceased (Franklin and Dyrness 1984).

Grazing was curtailed considerably in Unit E in 1992; conversely, AUMs in Grazing Unit D were increased during 1992 over previous years. This and past grazing management may have affected species composition of vegetation, reducing vegetative diversity at the Hanson Creek site that is located in Grazing Unit E. Species occurrence at the North Bivouac site may suggest that the area is in some stage of recovery or that past grazing practices did not reduce species diversity of the site to the extent noted for Hanson Creek. Results of trapping indicate a similar reduction in number and diversity of small mammal species at the Hanson Creek site. It may be speculated that past practices reduced vegetative diversity and subsequently number and diversity of small mammals at the site.

\subsection{Human Disturbance on the Yakima Training Center}

In comparison to the grazed sites, the sites characterized by disturbance from human debris and presence of track and wheel vehicles maintained some similarities in number of species and abundance of small mammals. Training Area $8 \mathrm{~B}$ was similar to the North Bivouac site in terms of number of species encountered $(n=6)$ and number of individuals captured ( $n=131$ and 137, respectively). However, an important point about this result is the frequency of occurrence and type of disturbance recorded at Training Area $8 \mathrm{~B}$. The primary disturbance at this site was from human debris associated with bivouacs and vehicular traffic from wheel and track vehicles (see Table 3.11). Although small mammal numbers and species abundance were similar for Training Area 8B and the North Bivouac sites, vegetative characteristics of the sites differed.

Training Area $8 \mathrm{~B}$ was characterized by low stem density $(\mathrm{n}=129)$ and species diversity of shrubs. Big sagebrush was the only shrub species that occurred on the site, accounting for approximately 23\% cover. Herbaccous species included Agropyron (5\%), Poa (14\%), and Bromus (2\%). The number of shrub stems varied from the North Bivouac site (i.e., 129 versus 317 ); however, the percent cover of shrub species did not vary greatly (23\% versus $18 \%$ ). The similarity in number of species and abundance of small mammals at Training Area 8B and the North Bivouac site may be a function of species composition of vegetation as well as shrub canopy cover.

This can be examined further with regard to results for Training Area $8 \mathrm{~B}$ and the Silica site. Vegetation at the Silica site and Training Area 8B was similar in percent cover of big sagebrush (22.6\% versus $22.8 \%$, respectively) and species diversity of shrubs (see Table 3.10 ) as well as the species complement of herbaceous vegetation. These two sites did differ, however, in percent cover of all vegetation calculated from Daubenmire plots (33\% versus 60\%). At the Silica site, percent cover of vegetation was greater, with many small-statured shrubs accounting for a large percentage of vegetative cover. Conversely, Training Area $8 \mathrm{~B}$ was characterized by fewer plants but of larger stature. The difference in success of small mammal captures at these sites was noted not in species diversity but in number of small mammals trapped, which was significantly lower at the Silica site (131 versus 20) (see Table 3.6). In addition to species composition and percent cover of shrubs, vegetation structure may affect abundance of small mammals.

The herbaceous component of the Silica site was similar to the sites that were grazed but did not appear (from soil compaction and rubbing of shrubs) to be overgrazed, and retained high species 
diversity. Disturbance from wheel and track vehicles at the Silica site may have altered vegetation structure, and recovering plants may not provide adequate habitat for a large number of small mammal species. Studies examining vegetation distribution and occurrence of small mammals (Murphy 1978, Wakeley 1978, Call 1979, Feldhamer 1979, Littlefield et al. 1992, Baker and Brooks 1981), have identified percent cover and structure of vegetation as characteristics that affect habitat use. Hanson Creek, North Bivouac, and Training Area 8B did not differ significantly in species diversity. However, Lagurus curtatus was absent from the Silica site. Unlike the North Bivouac and Training Area 8B site, the Silica site was characterized by many small-statured sagebrush (see Table 3.10), and habitat suitability at the site may have been limited for the species. Sagebrush voles occur in loose soils in association with sagebrush, requiring green vegetation of the plant for forage (Burt and Grossenheider 1976). Compacted soils and limited sagebrush may have reduced habitat potential for voles at the silica site.

\subsection{Prey Species}

Wakely (1978) could not identify a direct relationship between rodent biomass and use of an area by foraging ferruginous hawks, suggesting that diversity of vegetation was more critical in birds' choice of foraging areas than was prey density. A general perception regarding ferruginous hawk prey selection is that if a broad prey base or an alternate prey species are available, birds can inhabit an area. In the absence of this, Woffinden and Murphy (1989) speculate that birds exhibit nomadic behavior and often relocate nesting territories. The results of trapping efforts during June through August 1993 suggest that a diversity of prey species occur on the YTC. Variations in species abundance and distribution are likely associated with the type and duration of disturbance to an area. As duration of disturbance alters vegetative structure and soil type affects capacity for colonization of species, small mammal abundance and distribution may be limited.

Use of small mammals by ferruginous hawks was determined from analysis of pellets collected at the nest site during August 1993. Sagebrush voles and deer mice accounted for $75 \%$ of small mammal remains (53\% of total individuals) in ferruginous hawk castings. Although the number of individual Leporids could not be corroborated from castings, this group represented $31 \%$ of all remains in ferruginous hawk castings, representing the primary forage of birds. The use of rabbits by ferruginous hawks has been well documented (Lokemoen and Duebbert 1976, Thurow et al. 1980, Steenhof 1983, Stalmaster 1988). However, rabbits have been ranked as third in importance as a primary forage species of ferruginous hawks in Washington (Olendorff 1993). Fitzner et al. (1977) identified pocket gophers as the primary prey species of ferruginous hawks in Washington. However, Fitzner et al. (1977) maintained that diet varied relative to the habitat in which birds were nested. Therefore, in the absence of this species, birds adapt to alternate sources of prey. It appears from 1993 results for a nested pair of ferruginous hawks on YTC that pocket gophers occurred significantly less than Leporids (8\%) and that other species comprised a greater percentage of the overall diet (i.e., sagebrush voles [23\%], deer mice [17\%], other Cricetid rodents [15\%]). It should be noted that Fitzner et al. (1977) did not observe any remains of pocket gophers in the diets of hawks nested in desert shrub habitat.

Pocket gophers comprised $83 \%$ and $91 \%$ of small mammal remains in ferruginous hawk pellets collected on the U.S. Department of Energy Hanford Site during 1992 and 1993, respectively. Microtine rodents comprised $6.5 \%$ and $2.1 \%$ of total individuals identified during these periods, respectively, and all other species accounted for less than $4 \%$ of the mammalian portion of the birds' diets (K. Lehmkuhl, personal communication, October 1993). These findings are consistent with the observations of Fitzner et al. (1977) for eastern Washington; therefore, we may suggest that given the availability of pocket gophers, ferruginous hawks would rely on them as their primary forage species. 
During 1993, it appeared that the nested pair of ferruginous hawks on YTC used Leporids more often; however, this group did not account for a significant portion of the birds' diet and, in fact, the diet appeared to be quite varied. This variety of groups, including reptiles, birds, and insects was also observed by other researchers in eastern Washington during 1992 and 1993 (K. Lehmkuhl, personal communication, October 1993).

The results of pellet analysis illustrate a reliance by the birds on a variety of prey species. It stands to reason that in the absence of an abundance of pocket gophers, ferruginous hawks would rely on other species. In analysis of prey-switching behavior by ferruginous hawks, Black and Frischknecht (1971) concluded that a reduction in major prey species, which was thought to be limiting the ferruginous hawk population under study, was not indexed according to changes in number of individuals available because diet shifts were not commensurate with prey species declines. Instead, the reduction in prey species was indexed by an overall reduction in reproductive success of the birds. This result may indicate a trend that has influenced ferruginous hawk use of YTC over the previous 6 years. Visits to the nest site were limited during incubation and rearing to minimize disturbance to birds. During August 1993, when it appeared that young had fledged, we conducted a survey of the nest sites and perch sites nearby to collect pellets and remains of prey items that may have been cast during rearing. During the site visit, one carcass of a juvenile ferruginous hawk was collected. From initial observations of the nest, we concluded that the nest was occupied by two juvenile ferruginous hawks and assumed that only one bird survived to fledging. This result is consistent with Stalmaster's findings for Swainson's hawk production on the YTC during 1993. Stalmaster concluded from preliminary observations that nested Swainson's hawks were undernourished and underdeveloped and that average clutch size was reduced (M. Stalmaster, personal communication, August 1993). 


\subsection{Management Recommendations}

Habitat management for ferruginous hawks requires maintenance of nesting substrate, maintenance of prey base, and limitations on direct human disturbance (Olendorff and Fish 1985). In the absence of suitable nest substrate, man-made structures can be provided for birds. It appears that nesting habitat on the YTC is not limited for ferruginous hawks or other raptor species, e.g., Swainson's hawk, prairie falcon, golden eagle (M. Stalmaster, personal communication August 1993); therefore, management recommendations for nest sites are not discussed here. It is likely that effects on ferruginous hawks at the YTC have resulted either directly from human intrusion or indirectly from habitat alteration. Results of small mammal trapping during 1993 would suggest that prey species abundance and distribution may be limiting birds' use of the YTC, and that habitat management may be necessary to restore prey species diversity and population densities of small mammals. Wakely (1978) speculated that raptors may forage in areas where cover conditions render prey more vulnerable; thus, areas that support many concealed individuals may not benefit hawks as well as "open" areas that support fewer individuals. The trap sites surveyed during 1993 fell into Wakeley's "moderate" category of $20 \%$ to $75 \%$ vegetative cover. In Wakely's analysis, this cover class was used less than expected by foraging ferruginous hawks. This result suggests that not only should some areas of the YTC be managed for prey species enhancement but also for restoration or maintenance of foraging habitat suitability. Management of prey base requires an understanding of varying types of disturbance and the degree of impact imported. The present study provided some information regarding species occurrence (i.e., number and diversity) in areas subject to varying types of disturbance. A first step to managing ferruginous hawks should include verification of trends in prey species distribution in varying habitats across YTC. Once understood, vegetationdisturbing activities should be managed to maintain patch diversity or maximize edge effect.

Habitat suitability index (HSI) criteria for ferruginous hawks (Jasikoff 1982) assume that prey species abundance is related to volume and structure of herbaceous and shrub vegetation. The criteria further assume that dense, tall vegetation will provide abundant prey but poor accessibility of prey for ferruginous hawks. Therefore, an optimum complement of food and vegetation components will be realized when the average height of plants is 15 to $60 \mathrm{~cm}$ corresponding with vegetative cover of $60 \%$ to $100 \%$. Wakely (1978) observed that ferruginous hawks foraged in areas characterized by bare ground and pasture significantly more than expected and that this behavior was not necessarily associated with abundance of prey species but with accessibility to forage.

Based on HSI criteria and results of 1993 surveys, the YTC provided a suitability rating between approximately 0.01 and 0.51 (on a scale of 0.0 to 1.0) (Jasikoff 1982). Range 55 and Training Area $8 \mathrm{~B}$ were the least and the greatest, respectively, for optimal production. Verification of these results would take into account the abundance of small mammals in related types of habitat throughout the site:

- The HSI model criteria, which are based on physical attributes of the habitat, warrant extensive small mammal trapping and vegetation surveys throughout the ferruginous hawk nesting season.

- Sampling across large blocks or habitat types on YTC and verification of cover type and percentage of each type across the site should be incorporated into a stratified random sample of small mammal abundance and distribution on YTC. 
Habitat management that would accommodate site activities and contribute to overall management for the species should follow these guidelines:

- In patches of sagebrush, manage fires so as not to alter large tracts (i.e., $>600 \mathrm{~m}$ ) of habitat, thus creating large monocultures, reducing structural diversity within patches, and increasing the potential for invasion of noxious weeds.

- Based on success of current rehabilitation efforts, continue habitat restoration with plantings of native shrubs and seeding with native grasses.

- Manage grazing to minimize soil compaction, erosion, and decreased capacity for establishment of noxious or undesirable species (Olendorff 1993).

- Restrict off-road vehicle travel in mature sagebrush stands to avoid destruction of individual plants. Conduct walk-through surveys and, if necessary, relocate bivouacs to avoid use of mature sagebrush stands and eliminate trampling of individual plants.

Ferruginous hawks' ability to acclimate to constant disturbance has been established (Olendorff and Stoddart 1974, Gilmer and Stewart 1993). However, limitations on distance or line of sight of activities must have restrictions. Management of training actiyities that will contribute to species maintenance activities should follow these guidelines:

- Post known active nest or perch sites with "No Trespassing" or "Alert" signs to reduce the incidence of "random" visitation to nests. Post areas at $450 \mathrm{~m}$ (minimum) and $800 \mathrm{~m}$ (maximum) from nest (Olendorff and Fish 1985, Sutter and Jones 1981).

- Limit use of training areas and ranges in the vicinity (i.e., within $800 \mathrm{~m}$ ) of known active nests during March through August.

- Restrict use of live rounds on ranges adjoining (i.e., within $800 \mathrm{~m}$ ) known active nests during March through August.

- Impose road closures, foot traffic, and prolonged activities (i.e., one-half hour to several days) within $800 \mathrm{~m}$ of known active nests during March through August.

- Limit use of helicopters or fixed-wing aircraft within $500 \mathrm{~m}$ of known active nests to survey and/or monitoring activities during March through August. 


\subsection{References}

Baker, J. A., and R. J. Brooks. 1981. "Raptor and Vole Populations at an Airport." J. Wildl. Manage. 45:390-396.

Black, H. L., and N. C. Frischknecht. 1971. "Relative Abundance of Mice on Seeded SagebrushGrass Range in Relation to Grazing." U.S. Department of Agriculture Forest Service Research Notes, INT-147, Washington, D.C.

Burt, W. H., and R. P. Grossenheider. 1976. A Field Guide to the Mammals of America North of Mexico. Hougton Mifflin, Boston.

Call, M. W. 1978. "Nesting Habitats and Surveying Techniques for Common Western Raptors." Tech. Note TN-316, U.S. Department of the Interior, Bureau of Land Management, Denver, Colorado.

Call, M. W. 1979. "Habitat Management Guides for Birds of Prey." Technical Note TN-338, U.S. Department of the Interior, Bureau of Land Management, Washington, D.C.

Cox, D. R. 1969. "Some Sampling Problems in Technology." In New Developments in Survey Sampling. pp. 506-527. Wiley Interscience, New York.

Daubenmire, R. 1959. "A Canopy-Coverage Method of Vegetational Analysis." Northw. Sci. 33:43-64.

Davis, D. E. 1982. Handbook of Census Methods for Terrestrial Vertebrates. CRC Press, Boca Raton, Florida.

Feldhamer, G. A. 1979. "Vegetative and Edaphic Factors Affecting Abundance and Distribution of Small Mammals in Southeast Oregon." Great Basin Nat. 39:207-218.

Fitzner, R. E., and R. L. Newell. 1989. "Ferruginous Hawk Nesting in the U.S. DOE Hanford Site: A Recent Invasion Following Introduction of Transmissions Lines." In Proceedings IV: Issues and Technology in the Management of Impacted Wildlife, pp. 125-132. Thorne Ecological Institute, Boulder, Colorado.

Fitzner, R. E., D. Berry, L. L. Boyd, and C. A. Rieck. 1977. "Nesting of Ferruginous Hawks (Buteo regalis) in Washington 1974-75." Condor 79:245-249.

Franklin, J. F., and C. T. Dymess. 1984. Natural Vegetation of Oregon and Washington. Oregon State University Press, Corvallis, Oregon.

Fyfe, R. W., and H. I. Armbruster. 1977. "Raptor Management in Canada." In World Conference on Birds of Prey, pp. 228-242. International Council for Bird Preservation, Vienna.

Gilmer, D. S., and R. E. Stewart. 1983. "Ferruginous Hawk Populations and Habitat Use in North Dakota." J. Wildl. Manage. 47:146-157.

Hodson, K. 1968. "Porcupine in Ferruginous Hawk's Nest." Blue Jay 26:180-181. 
Howard, R. P., and M. L. Wolfe. 1976. "Range Improvement Practices and Ferruginous Hawks." J. Range Manage. 29:33-37.

Kochert, M. N., K. Steenhof, and J. H. Doremus. 1986. "Ferruginous Hawk Nesting Surveys in the Snake River Birds of Prey Area: Implications for Long-Term Monitoring." U.S. Department of the Interior, Bureau of Land Management, Boise, Idaho.

Jasikoff, T. M. 1982. Habitat Suitability Index Models: Ferruginous Hawk. FWS/OBS-82/10, U.S. Department of the Interior, Fish and Wildlife Service, Washington, D.C.

Littlefield, C. D., S. P. Thompson, and R. S. Johnstone. 1992. "Rough-legged Hawk Habitat Selection in Relation to Livestock Grazing on Malheur National Wildlife Refuge, Oregon." J. Wildl. Manage. 73:80-84.

Lokemoen, J. T., and H. F. Duebbert. 1976. "Ferruginous Hawk Nesting Colony and Raptor Populations in Northem South Dakota." Condor 78:464-470.

Murphy, J. R. 1975. "Status of a Golden Eagle Population in Central Utah, 1967-1973." In Status of Raptors, pp. 91-96. Buteo Books, Vermillion, South Dakotà.

Murphy, J. R. 1978. "Management Considerations for Some Western Hawks." Transactions of the 43rd North American Wildlife and Natural Resources Conference, pp. 241-251.

Olendorff, R. R. 1993. Status, Biology, and Management of the Ferruginous Hawks: A Review. Raptor Research and Technical Assistance Center Special Report, U.S. Department of the Interior, Bureau of Land Management, Boise, Idaho.

Olendorff, R. R., and A. M. Fish. 1985. The Biology of the Ferruginous Hawk: A Review. U.S. Department of the Interior, Bureau of Land Management, Sacramento, California.

Olendorff, R. R., and J. W. Stoddart, Jr. 1974. "The Potential for Management of Raptor Populations in Western Grasslands." Raptor Research Report 2:47-88.

Owens, R. A., and M. T. Myers. 1973. "Effects of Agriculture Upon Populations of Native Passerine Birds of an Alberta Fescue Grassland." Can. J. Zool. 51:697-713.

Phelan, F.J.S., and R. J. Robertson. 1977. "Predatory Responses of a Raptor Guild to Changes in Prey Density." Can. J. Zool. 56:2565-2572.

Phillips, P. 1939. "Distribution of Rodents in Overgrazed and Normal Grasslands of Central Oklahoma." Ecology 17:673-679.

Porter, R. D., and C. M. White. 1977. "Status of Some Rare and Lesser Known Hawks in Western United States." In World Conference of Birds of Prey, R.D. Chancellor, ed., pp. 39-57. International Council for Bird Preservation, Vienna, Austria.

Schmutz, J. K. 1987. "The Effect of Agriculture on Ferruginous and Swainson's Hawks." J. Range Manage. 40:438-440.

Schmutz, J. K., S. M. Schmutz, and D. A. Boag. 1980. "Coexistence of Three Species of Hawks (Buteo spp.) in the Prairie-Parkland Ecotone." Can J. Zool. 58:1075-1089. 
Smith, D. G., J. R. Murphy, and N. D. Woffinden. 1981. "Relationships Between Jackrabbit Abundance and Ferruginous Hawk Reproduction." Condor 83:52-56.

Smith, D. G., and J. R. Murphy. 1978. "Biology of the Ferruginous Hawk in Central Utah." Sociobiology 3:79-95.

Snow, C. 1974. "Habitat Management Series for Unique or Endangered Species. Ferruginous Hawk, Buteo regalis." Tech. Note Rep. 13, U.S. Department of the Interior, Bureau of Land Management, Denver, Colorado.

Stalmaster, M.V. 1985. Ferruginous Hawk Nesting Mitigation Study: 1985. ERO Resources Corp., Golden, Colorado.

Stalmaster, M. V. 1988. Ferruginous Hawk Nesting Mitigation Study: Final Report. ERO

Resources Corp., Denver, Colorado.

Steenhof, K. 1983. "Prey Weights for Computing Percent Biomass in Raptor Diets." Raptor Res. 17:15-27.

Steenhof, K., M. N. Cochert, and J. A. Roppe. 1993. "Nesting by Raptors and Common Ravens on Electrical Transmission Line Towers." J. Wildl. Manage. 57:271-281.

Sutter, G. W., and J. L. Jones. 1981. "Criteria for Golden Eagle, Ferruginous Hawk, and Prairie Falcon Nest Site Protection." Raptor Res. 15:12-18.

Thurow, T. L., C. M. White, R. P. Howard, and J. F. Sullivan. 1980. Raptor Ecology of Raft River Valley, Idaho. EG\&G, Idaho Falls, Idaho.

Wakely, J. S. 1978. "Factors Affecting the Use of Hunting Sites by Ferruginous Hawks." Condor 80:316-326.

White, C. M., and T. L. Thurow. 1985. "Reproduction of Ferruginous Hawks Exposed to Controlled Disturbance." Condor 87:14-22.

Woffinden, N. D. 1975. Ecology of the Ferruginous Hawk (Buteo regalis) in Central Utah:

Population Dynamics and Nest Site Selection. Ph.D. Dissertation, Brigham Young University, Provo, Utah.

Woffinden, N. D., and J. R. Murphy. 1977. "Population Dynamics of the Ferruginous Hawk During a Prey Decline." Great Basin Nat. 37:411-425.

Woffinden, N. D., and J. R. Murphy. 1989. "Decline of a Ferruginous Hawk Population: A 20Year Summary." J. Wildl. Manage. 53:1127-1132. 


\section{Distribution}

No. of

Copies

Offsite

12 DOE/Office of Scientific and Technical Information

Harriet Allen

Washington Department of Fish and Wildlife

600 Capital Way North

Olympia, WA 98501

Marc Bechard

Boise State University

Raptor Research Center

Department of Biology

1910 University Drive

Boise, Idaho 83725

Ken Brunner

U.S. Army Corps of Engineers

Seattle District

Environmental Resources Section

P.O. Box C-3755

Seattle, WA 98124

30 Commander

Yakima Training Center

ATTN: AFZH-Y-ENV

(Steven M. Kruger)

Yakima, WA 98901

Fred Dobbler

Washington Department of Fish and Wildlife

1550 Alder St. NW

Ephrata, WA 98823
No. of

Copies

Lisa Fitzner

Washington Department of Fish and Wildlife

Route 2

Box 21282

Benton City, WA 99320

5 R. W. Hanna

Department of the Army

HQ-I Corps

ATTN: AFZH-DEQ

Fort Lewis, WA 98433-5000

Onsite

DOE Richland Operations Office

R. D. Hildebrand

20 Pacific Northwest Laboratory

L. L. Cadwell

R. Mazaika (10)

L. E. Rogers

J. G. Stephan

Publishing Coordination

Technical Report Files (5)

\section{Routing}

R. M. Ecker

M. J. Graham

P. M. Irving

P. C. Hays/G. P. O'Connor (last)

Distr.1 